\title{
Identification and Localization of an Arachidonic Acid- Sensitive Potassium Channel in the Cochlea
}

\author{
Bernd H. A. Sokolowski, ${ }^{\star}$ Yoshihisa Sakai, ${ }^{\star}$ Margaret C. Harvey, and Dmytro E. Duzhyy \\ Departments of Otolaryngology-Head and Neck Surgery and Physiology and Biophysics, University of South Florida, Tampa, Florida 33612
}

Receptor cells of the auditory and vestibular end organs of vertebrates acquire various types of potassium channels during development. Their expression and kinetics can differ along the tonotopic axis as well as in different cell types of the sensory epithelium. These variations can play a crucial role in modulating sensory transduction and cochlear tuning. Whole-cell tight-seal recordings of isolated hair cells revealed the presence of an arachidonic acid-sensitive A-type channel in the short (outer) hair cells of the chicken cochlea. This polyunsaturated fatty acid blocked the A-current, thereby increasing the amplitude and duration of the voltage response in these cells. We identified the gene encoding this channel as belonging to a member of the Shal subfamily, Kv4.2. Expression of the recombinant channel shows half-activation and inactivation potentials shifted to more positive values relative to native channels, suggesting that the native channel is coexpressed with an accessory subunit. RT-PCR revealed that transcription begins early in development, whereas in situ hybridization showed mRNA expression limited to the intermediate and short hair cells located in specific regions of the adult cochlea. Additional localization, using immunofluorescent staining, revealed clustering in apical-lateral regions of the receptor cell as well as in the cochlear ganglion. These experiments provide evidence that in addition to membrane proteins modulating excitation in these receptor cells, fatty acids contribute to the coding of auditory stimuli via these channels.

Key words: hair cell; Kv4.2; cDNA; immunohistochemistry; transcription; development

\section{Introduction}

Voltage-gated $\mathrm{K}^{+}$channels, in the sensory and neuronal cells of the nervous system, are essential in sensory transduction and signal coding. Among these channels is a fast-inactivating, A-type channel that regulates action potential frequency and waveform (Connor and Stevens, 1971; Neher, 1971; Kaczmarek and Strumwasser, 1984; Rogawski et al., 1985) and modulates synaptic potentials postsynaptically (Daut, 1973). Pharmacologically, this channel is blocked in a dose-dependent manner by 4-amino pyridine (4-AP) and the polyunsaturated fatty acid (PUFA), arachidonic acid (AA). The effectiveness of PUFAs such as AA, however, is dependent on the gene subfamily that encodes the channel. AA is most efficient in blocking Shal channels, whereas Shaker (Kv1) or Shaw (Kv3) channels are either unresponsive or show only a small decrease in activity (Villarroel and Schwarz, 1996). AA is released from the membrane by phospholipases and diacylglycerols (Meves, 1994; Denson et al., 1999), and its effects are initiated either directly or indirectly via metabolites such as lipoxygenase, cyclooxygenase, or epoxygenase (for review, see Needleman et al., 1986; Meves, 1994). Once released, AA can initiate downstream messengers such as protein kinase $\mathrm{C}$ (PKC)

Received April 6, 2004; revised May 26, 2004; accepted May 27, 2004.

This study was supported by the National Organization for Hearing Research and National Institute on Deafness and Other Communication Disorders Grant DC04295 to B.H.A.S. We thank Dr. H. Hiel for technical advice on the in situ hybridization and Drs. P. Fuchs, P. Manis, and C. Doupnik for their helpful discussions.

*B.H.A.S. and Y.S. contributed equally to this work.

Correspondence should be addressed to Dr. Bernd Sokolowski, University of South Florida, Otology Laboratory MDC83, 12901 Bruce B. Downs Boulevard, Tampa, FL 33612. E-mail: bsokolow@hsc.usf.edu.

DOI:10.1523/JNEUROSCI.1291-04.2004

Copyright $\odot 2004$ Society for Neuroscience $\quad 0270-6474 / 04 / 246265-12 \$ 15.00 / 0$
(McPhail et al., 1984) and $\mathrm{Ca}^{2+}$ (Knepel et al., 1988; Krutetskaia et al., 2001).

Recordings made from isolated hair cells demonstrate the presence of transient currents in the vestibular and cochlear apparatus of birds and mammals (Eatock and Hutzler, 1992; Murrow, 1994). In chick cochlear hair cells, an A-type current $\left(I_{\mathrm{A}}\right)$, a delayed rectifier $\left(I_{\mathrm{K}}\right)$, and calcium-activated $\mathrm{K}^{+}$currents modulate stimuli initiated through the mechanically activated transduction channels in the stereocilia (Fuchs and Evans, 1990). Their expression and functional characteristics vary, depending on their position along the width and tonotopic length of the cochlea (Fuchs, 1992). $I_{\mathrm{A}}$ is found in short hair cells, which dominate the proximal regions of the cochlea. In contrast, $I_{\mathrm{A}}$ decreases in amplitude across the width of the distal half of the cochlea, where there is a gradient from short to tall hair cells, and is absent from the most distal regions, where tall hair cells dominate (Murrow, 1994). Interestingly, short hair cells are innervated by large caliciform efferent endings (Tanaka and Smith, 1978; Fischer, 1992), suggesting a role similar to that of mammalian outer hair cells, which regulate cochlear tuning. Although A-channels are found throughout much of the chick cochlea, little is known about their function or structure.

In the present study, we identify the gene that encodes the A-channel as a member of the Shal subfamily and show that transcript expression begins early in development and is specific to adult short and intermediate cells. We validate this finding by showing that the A-channel is AA sensitive and reveal that it contributes to shaping the voltage response of these hair cells. Immunostaining shows that the A-channel is clustered in specific regions of the receptor cells. The presence of this PUFA-sensitive 
channel and its putative amino acid structure suggests some intriguing mechanisms that may play a role in modulating signal processing during the transduction of sound.

\section{Materials and Methods}

Plaque hybridization. We screened a chick (Gallus gallus) cochlea cDNA library (gift from P. Fuchs, Johns Hopkins University, Baltimore, MD) that was synthesized and cloned into EcoRI and XhoI sites of ZAPRII (Stratagene, La Jolla, CA). RNA for cDNA library construction was extracted from the cochlear duct, which included tegmentum vasculosum, lagenar, hyaline, homogene, clear, sensory, and supporting cells. The library was screened for genes that encode transient, A-type $\mathrm{K}^{+}$channels and belong to the Shal subfamily. Approximately $1.6 \times 10^{6}$ independent recombinants were screened by plaque hybridization with a 375 bp probe made from rat Shal cDNA (rKv4.2) (gift from L. Jan, University of California San Francisco, San Francisco, CA) that included S4, S5, and S6 transmembrane regions of the rat Shal protein. The ${ }^{32} \mathrm{P}$-labeled probe was generated by random primed labeling (Boehringer Mannheim, Indianapolis, IN). Duplicate nylon membrane filters were hybridized with labeled probe in $30 \%$ formamide, $6 \times \mathrm{SSC}(1 \times \mathrm{SSC}=0.15 \mathrm{M} \mathrm{NaCl}, 0.015$ m sodium citrate, $\mathrm{pH} 7.0$ ), 50 mм HEPES, $\mathrm{pH}$ 7.0, $1 \times$ Denhardt's solution, $0.5 \%$ SDS, and $100 \mu \mathrm{g} / \mathrm{ml}$ salmon sperm DNA at $37^{\circ} \mathrm{C}$ for $18 \mathrm{hr}$. Filters were washed four times in $0.5 \times \mathrm{SSC}$ and $0.1 \% \mathrm{SDS}$ at $50^{\circ} \mathrm{C}$ for $2 \mathrm{hr}$ and exposed onto $\mathrm{x}$-ray film at $-70^{\circ} \mathrm{C}$. The Bluescript plasmid was excised from selective positive phage isolates using the ExAssist helper phage excision kit (Stratagene). Escherichia coli SURE strain was transformed with the excised plasmids to obtain sufficient plasmid for sequencing. Both strands of the selected samples were sequenced (Biotechnology Center, University of Florida, Gainesville, FL) as described below, with vector- and insert-derived primers at both strands. Sequencing revealed a partial isolate of chick Shal (cShal) cDNA, consisting of $1 \mathrm{~kb}$ that included the $\operatorname{poly}\left(\mathrm{A}^{+}\right)$tail but lacked a portion of the $5^{\prime}$ end.

$5^{\prime}$ Rapid amplification of cDNA ends. The remaining portion of the $5^{\prime}$ end was extended using $5^{\prime}$ rapid amplification of cDNA ends (5' RACE) (Invitrogen, Grand Island, NY) by constructing internal oligonucleotide primers on the basis of the known chick cDNA sequence. Total RNA from embryonic day 3 (E3) showed the highest expression level of cShal among the various developmental days examined and thus was used for first-strand cDNA synthesis. This synthesis was primed with a genespecific antisense oligonucleotide (GSP1) and purified from unincorporated GSP1 primer and deoxyribonucleoside triphosphate with a GlassMAX spin cartridge (Invitrogen). Terminal deoxynucleotidyl transferase was used to add homopolymeric tails to the $3^{\prime}$ ends of the cDNA, and tailed cDNA was amplified by PCR using a pair of nested gene-specific primers (GSP2, which anneals 5' to GSP1) and a complementary homopolymer containing an abridged anchor primer. After purification of the PCR product from the gel, using the QIAEX II Gel Extraction kit (Qiagen, Valencia, CA), a second PCR was accomplished using primer pairs (GSP3, which anneals 5' to GSP2) and an abridged universal amplification primer. This PCR product was purified from the gel and subcloned for sequencing into vector pCR2.1 (Invitrogen). 5' RACE was performed three times until cShal cDNA extended beyond the $5^{\prime}$ end of the open reading frame.

Sequencing. Recombinant double-stranded plasmids, as templates, were sequenced (Sequencing Core Laboratory, University of Florida, Gainesville, FL) using the ABI Prism Dye Terminator Cycle Sequencing Ready Reaction kit with AmpliTaq DNA Polymerase (PerkinElmer, Foster City, CA). The fluorescent-labeled extension products were analyzed on an Applied Biosystems Stretch DNA Sequencer (model 373; PerkinElmer). Oligo primers were designed using OLIGO 4.0 software (National Biosciences, Plymouth, MN) and synthesized at the DNA Synthesis Core Laboratory (University of Florida). Nucleotide sequences were aligned and assembled using programs in the Sequencher 3.0 software package (Gene Codes, Ann Arbor, MI). Lasergene software (DNASTAR, Madison, WI) was used to determine multiple alignments of sequences, predicted translation products, identification of hydrophobic transmembrane regions, putative voltage sensor domains, and glycosylation sites.
Construction of expression vectors. Full-length cShal cDNA was subcloned into mammalian expression vector pcDNA3.1 (+) (Invitrogen) for transfection and eventual functional expression studies that used the whole-cell tight-seal recording technique. Two 29 bp chimeric oligonucleotide primers were synthesized to facilitate subcloning. Both primers at the $5^{\prime}$ end had a CGC sequence immediately adjacent to the Bam $\mathrm{HI}$ sequence that improved Bam HI cleavage efficiency. The chimeric forward primer (BAM-F: $5^{\prime}$-CGC GGA TCC TCC CAG TGG CTG GAC TAG AA-3') included a 20 bp sequence complementary to cShal nucleotides 34-53. The chimeric reverse primer (BAM-R: 5'-CGC GGA TCC GCT TGA GCT CAG CTT GTA AG-3') included a 20 bp sequence complementary to cShal nucleotides 2033-2052. The 2019 bp PCR product was amplified, using Taq polymerase (Elongase Enzyme Mix; Invitrogen) with the above primer pair, cut by BamHI, and purified from the gel using the QIAEX II Gel Extraction kit (Qiagen). The purified cShal fragment was ligated into the alkaline phosphatase (AP)-treated, BamHI-cut pcDNA3.1 (+) vector and transformed into JM109-competent cells (Promega, Madison, WI). Transformants were screened for ampicillinresistant recombinant plasmids and extracted using the QIAfilter Plasmid Midi kit (Qiagen) according to the manufacturer's protocol. The reverse-inserted clone served as a negative control.

Transfection. Cotransfection was accomplished using pcDNA3.1 (+), p3, and pBS expression vectors that contained $\mathrm{cKv} 4.2$, the lymphocyte surface antigen CD8 $\alpha$ (gift from B. Seeds, Massachusetts General Hospital, Boston, MA), and T-antigen, respectively. Vectors were mixed at a concentration of $0.8 \mu \mathrm{g}$ each in $100 \mu \mathrm{l}$ of OptiMEM (Invitrogen). This solution was mixed with a $100 \mu$ l solution of OptiMEM containing $2 \mu \mathrm{l}$ of Lipofectamine (Invitrogen) and incubated at room temperature for 45 min. Chinese hamster ovary $(\mathrm{CHO})$ cells, grown on sterile coverslips in $35 \mathrm{~mm}$ culture dishes, were covered with this solution and incubated at $37^{\circ} \mathrm{C}$ in a $5 \% \mathrm{CO}_{2}$ atmosphere for $12-24 \mathrm{hr}$. Before recording, cells were rinsed two times with a normal divalent saline solution containing (in $\mathrm{mm}$ ): 5 glucose, $154 \mathrm{NaCl}, 6 \mathrm{KCl}, 2.3 \mathrm{MgCl}_{2}, 5.6 \mathrm{CaCl}_{2}$, buffered with 5 mM HEPES, and brought to a $\mathrm{pH}$ of 7.4 with $1 \mathrm{~N} \mathrm{NaOH}$. Then, cells were covered with a similar solution containing beads coated with an antibody to the CD8 receptor (1:1000) (Dynabeads, Dynal, Lake Success, NY). The cells were incubated in the $35 \mathrm{~mm}$ dish on a rotary platform for $10 \mathrm{~min}$ at $37^{\circ} \mathrm{C}$ to allow the beads to attach. Once attached, the dish of $\mathrm{CHO}$ cells was placed on the platform used for recording. A construct, consisting of the cKv4.2 cDNA insert cloned in the opposite direction with respect to the cytomegalovirus promoter of pcDNA3.1(-), was used as a control.

Hair cell recordings. Hair cells were isolated from 2- to 3-week-old White Leghorn (G. gallus) chicks in compliance with the NIH Guide for the Care and Use of Laboratory Animals and the Institutional Animal Care and Use Committee guidelines. Animals were decapitated, and the head was bisected and immediately placed on ice. Chick cochleas were removed from the temporal bone in ice-cold divalent saline, and the tegmentum vasculosum was cut away with iridectomy scissors. As described previously (Fuchs and Sokolowski, 1990), the cochlea was placed in a low-calcium saline containing protease XXIV $(0.09 \mathrm{mg} / \mathrm{ml})$ (Sigma, St. Louis, $\mathrm{MO}$ ), and the tectorial membrane was removed with forceps after 2-4 min. The cochlea was rinsed in normal divalent saline containing BSA $(0.5 \mathrm{mg} / \mathrm{ml}$; Sigma $)$ and then in saline alone. Hair cells were removed by aspiration with a borosilicate micropipette and placed in a recording dish. During recordings, cells were maintained in an oxygenated divalent saline solution containing (in $\mathrm{mm}$ ): 5 glucose, $154 \mathrm{NaCl}, 6$ $\mathrm{KCl}, 2.3 \mathrm{MgCl}_{2}, 5.6 \mathrm{CaCl}_{2}$, buffered with $5 \mathrm{~mm}$ HEPES, and brought to a $\mathrm{pH}$ of 7.4 with $1 \mathrm{~N} \mathrm{NaOH}$. This bath solution has been used previously for isolated hair cells from chickens because it maintains their integrity during recordings at various stages of development (Fuchs and Evans, 1990; Fuchs and Sokolowski, 1990; Murrow, 1994; Sokolowski et al., 1993). Electrical recordings were made at a room temperature of $\sim 25^{\circ} \mathrm{C}$ with borosilicate glass electrodes, as described previously (Sokolowski et al., 1993), that were filled with a solution containing (in $\mathrm{mM}$ ): $112 \mathrm{KCl}, 0.1$ $\mathrm{CaCl}_{2}, 2 \mathrm{MgCl}_{2}, 30 \mathrm{KOH}, 11$ EGTA, buffered with 10 mM HEPES. ATP (5 $\mathrm{mm}$ disodium salt; Sigma) was added before adjusting the $\mathrm{pH}$ to 7.2 with $1 \mathrm{~N} \mathrm{KOH}$ for the purpose of reducing the rundown of currents. For pharmacological studies, hair cells were superfused with $10 \mathrm{~mm}$ 4-AP (Sigma), 10, 20, or $30 \mu \mathrm{M} \mathrm{AA}$, or $30 \mu \mathrm{M} 5,8,11,14$ eicosatetraynoic acid 
GTGTCTATGCAA CTGAGCGCTCTCGCCAGACTTTCCCAGTGGCTGGACTAGAACTGTCTGTATATTCACTCTCTCAGCTGTAGTAG CIGITIGGGACCATGGCAGCGGGCGTAGCAGCITGGTTACCCTHTGCCAGGGCAGCAGCCATAGGATGGATGCCAGTGGCCACAGG

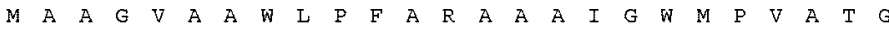

TCCCATGCCAGCTGCTCCACGGCAGGAGAGGAAGCGAAGCCAAGACTCTCTGATCGTGCTGAATGTGAGTGGCATCCAGTTCCAGA 258

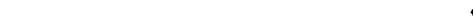

CGIGGCTGGACACCITGGAGCGCIACCCIGACACTCIGCIGGGCAGITCAGAGCGGGACITCITITACCACCCIGAGACACAGCAG 344 $\begin{array}{llllllllllllllllllllllllllllllll}54 & T & W & L & D & T & L & E & R & Y & P & D & T & L & L & G & S & S & E & R & D & F & F & Y & H & P & E & T & Q & Q\end{array}$

TACTTTTTCGATCGGGACCCTGACATTTTCCGCCACATTCTCAACTTCTACCGTACTGGGAAGCTCCATTACCCCCGCCAGGAGTG 430 $\begin{array}{lllllllllllllllllllllllllllllllllll}83 & Y & F & F & D & R & D & P & D & I & F & R & H & I & L & \text { N } & F & Y & R & T & G & K & L & H & Y & P & R & Q & E & C\end{array}$

CATCTCTGCTTACGATGAGGAGCTGGCCTTTTTGGCATCATCCCAGAGATCATTGGTGACTGCTGTTATGAGGAGTACAAGGATC 516

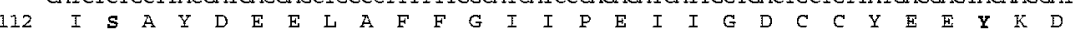

GCCGGCGTGAGAACGCTGAGCGCCTGCAGGACGATGCTGACCAGGATCACACAGCCGAGAGCTCCCTCCCCTCGATGACAGCTCGG 602 $\begin{array}{lllllllllllllllllllllllllllllll}140 & R & R & R & E & N & A & E & R & L & Q & D & D & A & D & Q & D & H & T & A & E & S & S & L & P & S & M & T & A & R\end{array}$

CAGAGGATGTGGCGGGCTTTGAAACCCACACACCAGTACGCTGGCTCTGGTCTICTACTATGTCACTGGTTTTTCATTGCTGT 688 $\begin{array}{lllllllllllllllllllllllllllllllll}169 & Q & R & M & W & R & A & F & E & N & F & H & T & S & T & L & \text { A } & L & V & F & Y & Y & V & T & G & F & F & I & A & V \\ \end{array}$ CTCIGTTATTGCCAATGTGGIGGAGACAGTGCCCTGTGGGGTGAGCCGGGTCGCATCAAGGAGCTGCCCTGTGGAGAGCGCTACG 774 $\begin{array}{lllllllllllllllllllllllllllllllll}198 & S & V & I & A & \text { N } & V & V & E & T & V & P & C & G & V & S & P & G & R & I & K & E & L & P & C & G & E & R & Y\end{array}$ $\uparrow$ CTGIGGCTITCTTCTGTCTGGATACTGCTTGTGTCATGATCTTCACAGTTGAATATCTCCTACGCCTGCTGGCAGCTCCGAGTCGC 860 $\begin{array}{llllllllllllllllllllllllllllll}226 & A & V & A & F & F & C & L & D & T & A & C & V & M & I & F & T & V & E & Y & L & \text { L } & R & \text { L } & \text { L } & \text { A } & \text { A } & P & S & R\end{array}$

TACARATTCGTGCGCAGTGTCATGAGTATCATPGATGTGGTAGCCATTATGCCGTATTACATTGGCCTGGIGATGACAGATA.ATGA 946 $\begin{array}{lllllllllllllllllllllllllllllll}255 & \mathrm{Y} & \mathrm{K} & \mathrm{E} & \mathrm{V} & \mathrm{R} & \mathrm{S} & \mathrm{V} & \mathrm{M} & \mathrm{S} & \mathrm{I} & \mathrm{I} & \mathrm{D} & \mathrm{V} & \mathrm{V} & \mathrm{A} & \mathrm{I} & \mathrm{M} & \mathrm{P} & \mathrm{Y} & \mathrm{Y} & \mathrm{I} & \mathrm{G} & \mathrm{L} & \mathrm{V} & \mathrm{M} & \mathrm{T} & \mathrm{D} & \mathrm{N} & \mathrm{E}\end{array}$ s3

GGACGTCAGTGGGGCTTTTGIGACACTAAGAGTCTITCGTGTCTTCAGGATCTTTAAGTTTTCCCGCCACTCACAGGGGCTGCGCA 1032

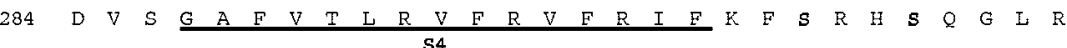

TCCTGGGCTACACCCTCAAAAGCTGCGCCTCGGAGTTAGGCTTCCTCCTCTTCTCACTCACCATGGCCATCATCATCTTTGCCACA 1118

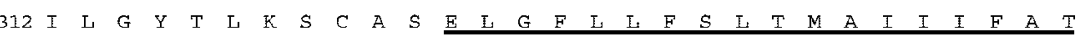
- $\quad s 5$ GTCATGTACTATGCAGAGAAAGGTTCATCAGCCAGCAAGTTCACCAGCATCCCCGCAGCCTTCTGGTACACCATTGTCACCATGAC 1204

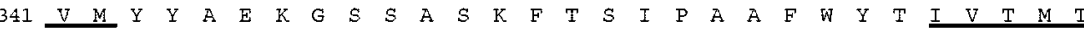
AACACTGGGGTATGGTGACATGGTGCCGAAGACAATAGCTGGCAAGATTTTTGGTTCAATATGCTCCTTGAGTGGAGTCTTAGTGA 1290 \begin{tabular}{llllllllllllllllllllllllllllll}
370 & $\mathrm{~T}$ & $\mathrm{~L}$ & $\mathrm{G}$ & $\mathrm{Y}$ & $\mathrm{G}$ & $\mathrm{D}$ & $\mathrm{M}$ & $\mathrm{V}$ & $\mathrm{P}$ & $\mathrm{K}$ & $\mathrm{T}$ & $\mathrm{I}$ & $\mathrm{A}$ & $\mathrm{G}$ & $\mathrm{K}$ & $\mathrm{I}$ & $\mathrm{F}$ & $\mathrm{G}$ & $\mathrm{S}$ & $\mathrm{I}$ & $\mathrm{C}$ & $\mathrm{S}$ & $\mathrm{L}$ & $\mathrm{S}$ & $\mathrm{G}$ & $\mathrm{V}$ & $\mathrm{L}$ & $\mathrm{V}$ \\
\hline
\end{tabular} TTGCTCTGCCAGTTCCIGTAATTGTCTCCAACITCAGCCGTATCTACCACCAGAACCAACGAGCAGACAAGCGCAGGGCACAAAAG 1376 $\begin{array}{llllllllllllllllllllllllllllllll}398 & I & A & L & P & V & P & V & I & V & S & N & F & S & R & I & Y & H & Q & \text { N } & Q & R & A & D & K & R & R & A & Q & K\end{array}$ AAAGCAAGACTTGCTCGAATTCGIGCGGCAAAGAGTGGGAGTGCTAATGCCTACATGCAGAGCAAACGGAATGGCTTACTGAGTAA 1462 $\begin{array}{llllllllllllllllllllllllllllll}427 & \text { K } & \text { A } & \text { R } & \text { L } & \text { A } & \text { R } & \text { I } & R & \text { A } & \text { A } & \text { K } & \text { S } & \text { G } & \text { S } & \text { A } & \text { N } & \text { A } & \text { Y } & \text { M } & \text { O } & \text { S } & K & \text { R } & \text { N } & \text { G } & \text { L } & \text { L } & S & N\end{array}$

CCAGCTGCAGCAGTCCTCCAGTGA.GAAGACAGGCCTTGTTAGCAAGTCTGGCTCTTCCTTTGAAACGCAGCACCACCACCTGC 1548 $\begin{array}{llllllllllllllllllllllllllllll}456 & Q & L & Q & Q & S & S & S & E & E & E & Q & A & F & V & S & K & S & G & S & S & E & E & T & Q & H & H & H & I\end{array}$

TTCACTGCCTGGAAAAAACTACGAATCATGAATTTGTGGATGAACAGCTCTACGAAGAGAGCTGCATGGAGGTTTCTACAGTCAAT 1634

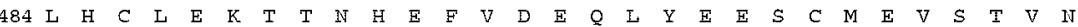

AGACCCCCGAGCCACAGCCCCTCGCTTTCGTCCCAACAAGGCGTCACTGGCACTTGCTGCICACGAAGACATAAAAAGACATACCG 1720 $\begin{array}{lllllllllllllllllllllllllllllll}513 & R & P & P & S & H & S & P & S & L & S & S & Q & Q & G & V & T & G & T & C & C & S & R & R & H & K & K & T & Y & R\end{array}$ CATCCCCAACACTGCCCTGACGGGCAGCCGCCACGGCAGCGTACAGGAGCTCAGCACCATCCAGATCAGATGTGTAGAGÄGGACAC 1806

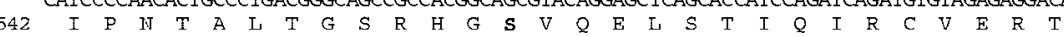

CTCTGTCTAACAGCCGATCCAGCTTAAATGCCAAAGTGGAAGAGTGCGTTAAACTAAACTGTGAGCAGCCTTACGTCACTACAGCA 1892 $\begin{array}{llllllllllllllllllllllllllllll}570 & \mathrm{P} & \mathrm{L} & \mathrm{S} & \mathrm{N} & \mathrm{S} & \mathrm{R} & \mathrm{S} & \mathrm{S} & \mathrm{L} & \mathrm{N} & \mathrm{A} & \mathrm{K} & \mathrm{V} & \mathrm{E} & \mathrm{E} & \mathrm{C} & \mathrm{V} & \mathrm{K} & \mathrm{L} & \mathrm{N} & \mathrm{C} & \mathrm{E} & \mathrm{Q} & \mathrm{P} & \mathrm{Y} & \mathrm{V} & \mathrm{T} & \mathrm{T} & \mathrm{A}\end{array}$

ATAATTAGCATCCCAACACCTCCIGTCACCACACCTGAAGGAGATGATAGGCCAGAGTCTCCTGAGTATTCGGGAGGAAACATTGT 1978

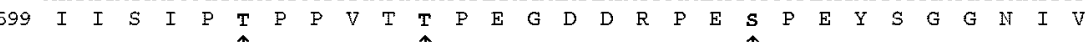

628 CAGAGTATCCGCTTTATAAA

GTCCCGAGGAATGAGAGAGCTGACAAAGACAACACCCCCTGATGCGTGTGCCAGCAGCAACGGAGTGAGACGITCAGGAGTACCAC 2150 AACAATTTGTGGCTGTCGGTGTCACAGCGTGGAAACCAATGCAGTTTCTATATACTGTTGGAACTGACACACAGTGGAAGCTTCTG 2236 TGACCATCCTGACTTACTATAGAGCACAATGAAATGTCCCCATTGATGCTTCTTCTTATCATGAGAGTTCTTITTAGA

Figure 1. The nucleotide and deduced amino acid sequence of cKv4.2. A hydrophilicity profile based on a Kyte and Doolittle (1982) analysis revealed the six transmembrane helices $\mathrm{S1}$ to S6 (underlined) and the conserved pore (H5) region of $\mathrm{K}^{+}$channel genes. Potential protein kinase phosphorylation sites included PKA (bold), PKC ( $\mathbf{p})$ ), and the mitogen-activated protein kinase, ERK (arrow). Also, two putative $\mathrm{N}$-glycosylation sites $(\downarrow)$ were identified.

(ETYA) (Sigma), using a gravity-fed, glass pipette array arranged $\sim 80$ $100 \mu \mathrm{m}$ from the cell. Fresh solutions of 4-AP (Sigma) were made before each experiment with equimolar concentrations of 4-AP replacing $\mathrm{NaCl}$. A 100 mm AA (Boehringer Mannheim) stock solution was made by mixing AA in $100 \%$ dimethyl sulfoxide. A 10,20 , or $30 \mu \mathrm{m}$ working solution was prepared by diluting the stock in divalent saline containing $0.1 \%$ DMSO. All tubes containing AA were wrapped in aluminum foil because 56

of its sensitivity to light. Fresh AA was made for each new dish of cells; nevertheless, AA proved to be extremely labile, losing its blocking efficiency within $1 \mathrm{hr}$. Furthermore, the amount of block varied within the same dose rate and between different lots obtained from the manufacturer. ETYA was used because it is an inhibitor of the cyclooxygenase and lipoxygenase branches of the AA pathway (Tobias and Hamilton, 1979). ETYA stock and working solutions were mixed and handled in a manner similar to AA. For the purpose of washing out AA or ETYA, a similar divalent saline solution was used, except that $1 \mathrm{mg} / \mathrm{ml}$ BSA replaced AA or ETYA. BSA binds fatty acids and accelerates the recovery from AA (Spector et al., 1969). In addition to isolating $I_{\mathrm{A}}$ pharmacologically, the current was isolated by its voltage-dependent properties. This method involved subtracting the current response to a depolarization, from an inactivating holding potential of $-43 \mathrm{mV}$, from the current response to a depolarization, from a noninactivating potential of -83 or -93 $\mathrm{mV}$. This method isolated $I_{\mathrm{A}}$ from other noninactivating currents because $I_{\mathrm{A}}$ was inactivated at $-43 \mathrm{mV}$ and not at $-83 \mathrm{mV}$ (see Figs. $2 A, B, 4 A$ ).

Voltage clamp was accomplished with an Axopatch 1D (Axon Instruments, San Francisco, CA) patch-clamp amplifier via an 88486 computer using pClamp (Axon Instruments) software and hardware. Data were analyzed using both pClamp and Origin software (Microcal Inc., Northampton, MA). Membrane potentials were corrected for the junction potential of $-3 \mathrm{mV}$ that resulted from the difference between internal and external solutions. Whole-cell capacitance, series resistance, and the clamp time constant were determined by using the transient decay from currents elicited with a $3 \mathrm{mV}$ step. This measurement resulted in mean values of $6.7 \pm 0.143 \mathrm{pF}, 7.3 \pm$ $0.49 \mathrm{M} \Omega$, and $47.2 \pm 3 \mu \mathrm{sec}(n=42)$, respectively.

$\mathrm{CHO}$ cell recordings. Bead-labeled cells were chosen for whole-cell tight-seal recordings at room temperature. During recording, $\mathrm{CHO}$ cells were bathed in a divalent saline solution that had the same composition and $\mathrm{pH}$ as the solution used for hair cell recordings. Electrical recordings were made at room temperature with borosilicate glass electrodes filled with a saline solution composed of the same salts as used for hair cell recordings. Membrane potentials were corrected for the junction potential of $-3 \mathrm{mV}$ that resulted from the difference between internal and external solutions. Wholecell capacitance, series resistance, and the average clamp time constant were determined as described above resulting in values of $15.1 \pm 1.1$ $\mathrm{pF}, 3.4 \pm 0.4 \mathrm{M} \Omega, 49 \pm 5 \mu \mathrm{sec}(n=25)$, respectively. Inactivation time constants were determined using a single-order exponential. All data presented as averages are given with the SEM.

Total RNA preparation and RT-PCR. The cochlea and brain from different embryonic or posthatched chicks were rapidly removed and microdissected in an ice-cold divalent saline solution consisting of (in $\mathrm{mM}$ ): 5 glucose, $154 \mathrm{NaCl}, 6 \mathrm{KCl}, 2.3 \mathrm{MgCl}_{2}, 5.6 \mathrm{CaCl}_{2}$ buffered with $5 \mathrm{~mm}$ HEPES, dissolved in DEPC-treated $\mathrm{H}_{2} \mathrm{O}$, and brought to a $\mathrm{pH}$ of 7.4 with 
$1 \mathrm{~N} \mathrm{NaOH}$. In addition, each cochlear duct from E10, E15, and posthatched day 1 (PD1) was microdissected into individual tissues consisting of cochlear epithelium, ganglion, lagena, and tegmentum vasculosum. Tissues were frozen in microcentrifuge tubes placed on dry ice and stored at $-80^{\circ} \mathrm{C}$. Total RNA from each tissue was extracted with Tri-Reagent (Molecular Research Center, Cincinnati, $\mathrm{OH}$ ) according to the manufacturer's protocol and treated with DNase I (GenHunter Corporation, Nashville, $\mathrm{TN})$ to remove genomic DNA. After treatment with phenol and chloroform, DNase I-treated total RNA was precipitated using an equal volume of isopropanol, washed with $80 \% \mathrm{EtOH}$, dried in air, and dissolved in DEPC- $\mathrm{H}_{2} \mathrm{O}$.

RT-PCR was performed on DNase I-treated total RNA extracted from the whole cochlear duct, brain, and each of the microdissected tissues obtained from E3, E6, E10, E15, and PD1. Recovered RNA was reverse-transcribed with oligo-d $\mathrm{T}_{12-18}$ primer using SuperScript II RNase $\mathrm{H}^{-}$Reverse Transcriptase (Invitrogen), which synthesizes the first-strand cDNA from mRNA and RNase H (Invitrogen), which removes the first-strand cDNA-annealed mRNA. After first-strand cDNA synthesis, each reverse transcriptase product was amplified by PCR using primer pairs specific to the $5^{\prime}$ region of cKv4.2. Primers, used at a concentration of 10 pmol, consisted of $5^{\prime}$-TCC CAG TGG CTG GAC TAG AA-3' (forward) and 5'-CCA GTA CGG TAG AAG TTG AG-3' (reverse). The PCR was run in a $25 \mu \mathrm{l}$ volume with the following parameters: TaqDNA polymerase was activated at $94^{\circ} \mathrm{C}$ for $1 \mathrm{~min}$, followed by 35 cycles at $94^{\circ} \mathrm{C}$ for $30 \mathrm{sec}, 55^{\circ} \mathrm{C}$ for $30 \mathrm{sec}$, and $72^{\circ} \mathrm{C}$ for $3 \mathrm{~min}$, with a final extension at $72^{\circ} \mathrm{C}$ for $10 \mathrm{~min}$. Equal amounts of cDNA were used in each PCR reaction. Expected PCR products of $250 \mathrm{bp}$ were observed on a $2 \%$ agarose gel containing $0.5 \mu \mathrm{g} / \mathrm{ml}$ ethidium bromide.

In situ hybridization. Antisense and sense cRNA probes were prepared using PCR to generate DNA fragments corresponding to $1970-2225 \mathrm{bp}$ of the cKv 4.2 cDNA. These fragments were inserted at the EcoRI and HindIII sites of transcription vectors pSPT18 and pSPT19 in opposite directions to the T7 promotor. Templates were purified using a gel extraction kit (Qiagen) and phenol chloroform followed by precipitation with ethanol. Templates were transcribed using a digoxigenin (DIG)labeling kit (Roche Applied Science, Indianapolis, IN). The bony portion surrounding the cochlea from PD15 chicks was partially removed, and the cochlea was immersion-fixed in $4 \%$ paraformaldehyde (PFA) in $0.1 \mathrm{M}$ phosphate buffer (PB), pH 7.4, overnight at $4^{\circ} \mathrm{C}$. Excess bone was removed the next day, and the cochlear duct was cryoprotected in $30 \%$ sucrose in $\mathrm{PB}$ overnight at $4^{\circ} \mathrm{C}$ followed by infiltration with OCT (Sakura FineTek, Tokyo, Japan) for $2 \mathrm{hr}$ under vacuum at room temperature. Tissues were snap-frozen in isopentane cooled with liquid nitrogen. Cryosections of $10 \mu \mathrm{m}$ thickness were collected on positively charged slides (Superfrost Plus; Fisher Scientific, Norcross, GA) using an HM505 cryotome (Richard-Allan Scientific, Sarasota, FL) set at $-15^{\circ} \mathrm{C}$, dried for $30 \mathrm{~min}$ at $60^{\circ} \mathrm{C}$, and stored at $-80^{\circ} \mathrm{C}$. Sections were brought to room temperature on the day of the experiment and fixed in ice-cold $4 \%$ PFA. Sections were permeabilized in $0.1 \%$ Triton X-100 in PB for 15 min, digested using $2 \mu \mathrm{g} / \mathrm{ml}$ proteinase $\mathrm{K}$ (Worthington, Lakewood, $\mathrm{NJ}$ ) for $25 \mathrm{~min}$ at $37^{\circ} \mathrm{C}$, postfixed in $4 \% \mathrm{PFA}$, and then acetylated in $0.25 \%$ acetic acid anhydride in $0.1 \mathrm{~m}$ triethanolamine buffer, $\mathrm{pH}$ 8.0. Then, sections were dehydrated and vacuum dried for $1 \mathrm{hr}$. Antisense and sense probes were heated for $5 \mathrm{~min}$ at $75^{\circ} \mathrm{C}$ and diluted in hybridization buffer consisting of $50 \%$ formamide, $250 \mu \mathrm{g} / \mathrm{ml}$ baker's yeast tRNA (Sigma), $0.1 \times$ Denhardt's solution, $10 \%$ dextran sulfate, $4 \times$ SSC, and $500 \mu \mathrm{g} / \mathrm{ml}$ dena-
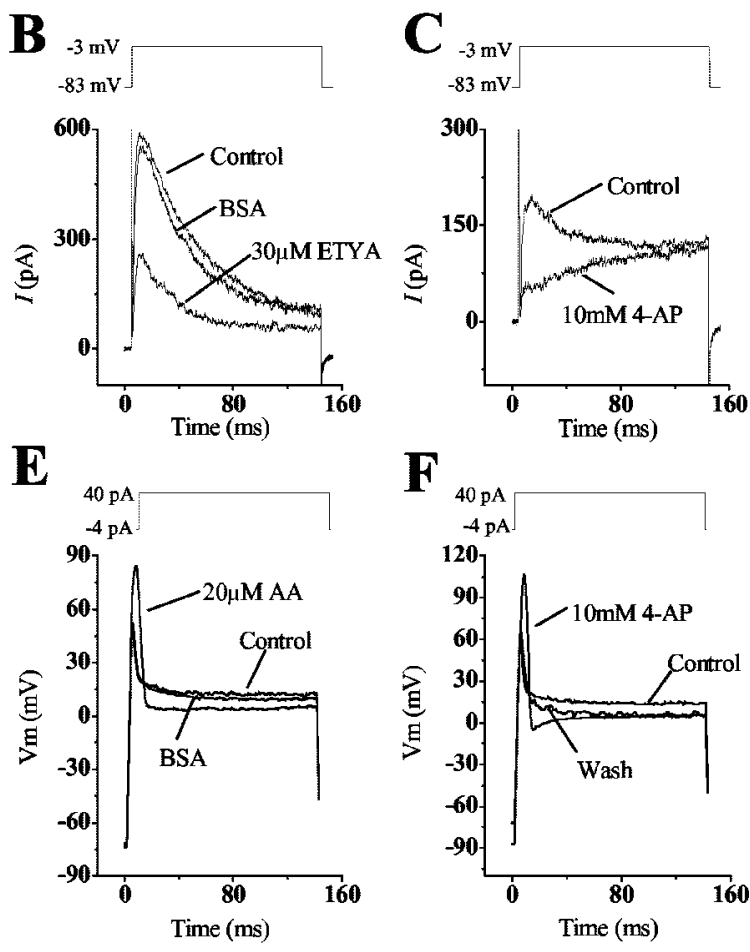

Figure 2. The A-current and its effects on the voltage response. $A-C$, The 4-AP-sensitive A-current found in short and intermediate hair cells was elicited by depolarizing the cell to $-3 \mathrm{mV}$ from holding potentials of $-83 \mathrm{mV}$. This current was blocked 列 $30 \mu \mathrm{m}$ AA and its nonmetabolic analog ETYA and blocked almost completely by $10 \mathrm{~mm}$ 4-AP. D, A transient voltage this transient voltage response. The results in $A$ are from a different cell than those in $E$ and $F$, which are from the same cell. The A-current response in $B$ and $C$ was isolated as outlined in Materials and Methods.

tured and sheared salmon sperm DNA (Invitrogen). The final probe concentrations were $1.6 \mathrm{ng} / \mathrm{ml}$. Sections were covered with the hybridization solution, heated for $2 \mathrm{~min}$ on a slide warmer set to $67^{\circ} \mathrm{C}$, coverslipped, and hybridized at $48^{\circ} \mathrm{C}$ overnight in a humidified chamber. Posthybridization washes consisted of two $30 \mathrm{~min}$ washes each in $25 \%$ formamide $/ 2 \times$ SSC and $1 \times$ SSC $/ 0.5 \times$ PBS $[1 \times$ PBS $($ in $\mathrm{mm})=150$ $\left.\mathrm{NaCl}, 3 \mathrm{Na}_{2} \mathrm{HPO}_{4}, 1 \mathrm{KH}_{2} \mathrm{PO}_{4}, \mathrm{pH} 7.4\right]$ at $48^{\circ} \mathrm{C}$. Sections were treated with $20 \mu \mathrm{g} / \mathrm{ml}$ of RNase A (Sigma) in NTE buffer (in mM: $500 \mathrm{NaCl}, 10$ Tris-base, 1 EDTA, pH 8.0), for $30 \mathrm{~min}$ at $37^{\circ} \mathrm{C}$ and rinsed two times for $30 \mathrm{~min}$ each in $0.5 \times \mathrm{SSC}$ at $37^{\circ} \mathrm{C}$. Sections were placed in blocking buffer of 5\% sheep serum (Sigma), $0.25 \%$ Triton X-100 TBS (in mM: 100 Tris$\mathrm{HCl}, 150 \mathrm{NaCl}, \mathrm{pH} 7.5)$, for $1 \mathrm{hr}$ followed by overnight incubation at $4^{\circ} \mathrm{C}$ with 1:500 sheep anti-DIG alkaline phosphatase-conjugated Fab antibody (Roche) in blocking buffer. Slides were washed in TBS and AP buffer consisting of (in mM): 100 Tris- $\mathrm{HCl}, 100 \mathrm{NaCl}, 50 \mathrm{MgCl}_{2}, \mathrm{pH} 9.5$. Enzymatic activity was visualized via development with nitroblue tetrazolium chloride (NBT)/5-bromo-4-chlor-indolyl-phosphate (BCIP) [0.34 mg/ml NBT in 70\% dimethylformamide (DMF); $0.18 \mathrm{mg} / \mathrm{ml} \mathrm{BCIP}$ in $100 \% \mathrm{DMF}$ ] in AP buffer overnight in the dark at room temperature. Slides were rinsed in $\mathrm{ddH}_{2} \mathrm{O}$ and $\mathrm{PBS}$ and coverslipped using an aqueous mounting medium (glycerol/PBS, 1:1). Samples were photographed with a Zeiss Universal light microscope.

Immunohistochemistry. Chick cochleas were dissected, fixed, embedded, and cut as described previously (Sokolowski and Cunningham, 1996, 1999). Briefly, dissected cochleas were fixed for $3 \mathrm{hr}$ in $95 \% \mathrm{EtOH}$ and $5 \%$ glacial acetic acid at $0-4^{\circ} \mathrm{C}$. Then, tissues were placed in $100 \%$ EtOH for $30 \mathrm{~min}$, followed by a graded series of ethanol mixed with polyester (v/v) wax (Gallard Schlesinger, New York, NY) at $37-40^{\circ} \mathrm{C}$. Sections were cut at $8-9 \mu \mathrm{m}$ into a bath containing ice-cold $\mathrm{ddH}_{2} 0$ and placed on gelatin-coated slides. Before staining, sections were dewaxed in a graded series of EtOH followed by two washes in PBS. Sections were 

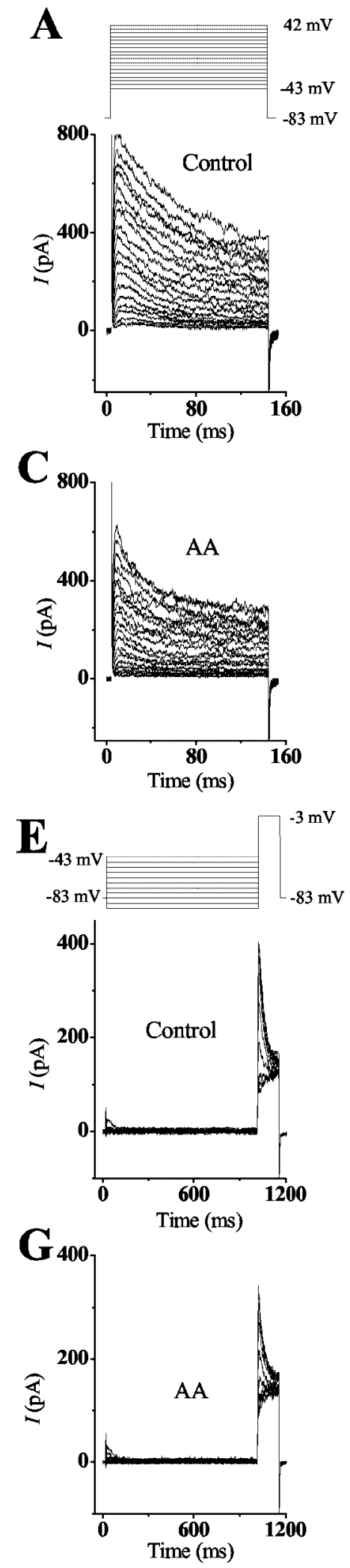

Figure 3. Conductance-voltage and steady-state inactivation properties are not altered with the addition of AA. $A, B$, The transient peak current in short and intermediate hair cells was elicited in a voltage-dependent manner. Depolarizing the cells in $5 \mathrm{mV}$ steps for $140 \mathrm{msec}$ from holding potentials of $-83 \mathrm{mV}$ elicited a transient current that began to activate within a range of $-43 \mathrm{to}-53 \mathrm{mV}$ and was completely activated at $42 \mathrm{mV}$. To determine the conductance, the peak current amplitude was divided by the driving force across the membrane using the reversal potential of $-83 \mathrm{mV}$ (obtained from tail current measurements not shown). Conductance values were normalized to the maximal conductance and plotted against the membrane

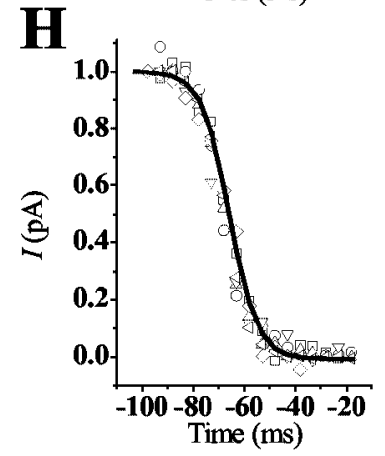

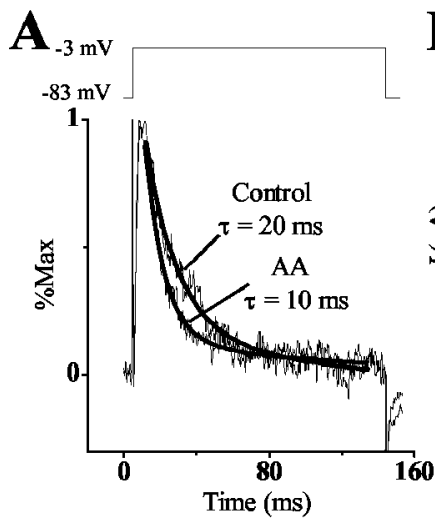

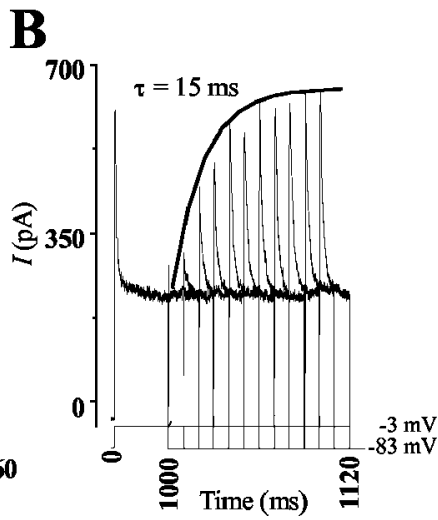

Figure 4. The inactivation time course of $I_{A}$ in hair cells. $A$, Inactivation of $I_{A}$ was affected by the addition of $A A$. Normalization of $I_{A}$ in control and $A A$ conditions shows that $A A$ increased the rate of inactivation. The rate of current inactivation was fit by a single-order exponential for both conditions. In the presence of $A A$ the rate of inactivation was $10 \mathrm{msec}$, whereas the rate in the control condition was $20 \mathrm{msec}$. B, Hair cells were voltage clamped to $-83 \mathrm{mV}$ and depolarized to $-3 \mathrm{mV}$ for $1 \mathrm{sec}$ to fully inactivate transient currents. A prepulse to $-83 \mathrm{mV}$ of increasing duration (10 msec intervals) was given to deinactivate the current, followed by a depolarizing test pulse to $-3 \mathrm{mV}$ to activate the deinactivated transient channels. The rate of recovery from inactivation was determined by plotting the peak $I_{A}$ generated against the prepulse duration. The solid line shows the curve fit generated for the responses using the equation $I=I_{\text {max }}\left(1-\exp ^{-T / \tau}\right)$, where $I / I_{\max }$ is the normalized peak $I_{A}$ generated for the time $T$ at -83 $\mathrm{mV}$. This fit generated the exponential time constant $\tau=15 \mathrm{msec}$.

blocked in 10\% goat serum (Sigma) in Tween PBS (TPBS) (0.05\% Tween $20,0.1 \%$ BSA in PBS) for $40 \mathrm{~min}$ at room temperature and then incubated overnight at $4^{\circ} \mathrm{C}$ in anti-Kv4.2 antiserum diluted 1:90 in TPBS containing $2 \%$ goat serum. The antibody consisted of a monoclonal raised against amino acids 209-225 (CGSSPGHIKELPSGERY) of the C-terminal region of rat Kv4.2 (gift from J. Trimmer, University of California, Davis, Davis, CA). This region is highly homologous to chick except for a substitution of valine for serine at position 211 and arginine for histidine at position 215 in chick. After washing two times in TPBS for $10 \mathrm{~min}$, tissue was incubated in an Alexa 488-conjugated goat anti-mouse secondary antibody (1:500; Molecular Probes, Eugene, OR) for $1 \mathrm{hr}$ at room temperature, followed by a $30 \mathrm{~min}$ wash with several changes of TPBS. Sections were mounted with Vectashield Mounting Medium for Fluorescence (Vector Laboratories, Burlingame, CA), which included a $4^{\prime}, 6^{\prime}$-diamidino-2-phenylindole (DAPI) nuclear stain. Slides were viewed with a Nikon Diaphot wide-field deconvolution microscope using ONCOR Image version 2.05 software. Images were captured with a

potential. The data were fit with a Boltzmann equation, $G / G_{\max }=1 /\left\{1+\exp \left[\left(V_{1 / 2}-V_{m}\right) / k\right]\right\}$, where $V_{\mathrm{m}}$ is the membrane potential. From this fit, the midpoint $\left(V_{1 / 2}\right)$, at which half the channels are activated, and the slope factor $(k)$, describing the voltage dependence of activation, were generated as $-9.7 \pm 1.3$ and $17.5 \pm 0.4 \mathrm{mV}(n=10)$, respectively. $C, D$, The addition of AA decreased the amplitude of the peak transient current but did not alter the conductance-voltage relationship. The voltages needed to begin $I_{A}$ activation and those needed for complete activation were similar to control conditions. Additionally, half activation and the slope factor showed no significant differences between control and AA conditions $\left(V_{1 / 2}\right.$ $=-9.8 \pm 0.8 \mathrm{mV} ; k=18.6 \pm 0.8 \mathrm{mV}) . E_{1} F$, Steady-state inactivation properties of the transient current were determined by presenting a prepulse of $1 \mathrm{sec}$, at the given membrane potentials, followed by a test pulse of $-3 \mathrm{mV}$ for $140 \mathrm{msec}$. The peak current during the test pulse was normalized to the maximal current obtained after a prepulse of $-103 \mathrm{mV}$. These responses were fit using the Boltzmann equation $I / I_{\max }=1 /\left\{1+\exp \left[\left(V_{\mathrm{m}}-V_{1 / 2}\right) / k\right]\right.$, where $V_{\mathrm{m}}$ is the membrane potential. This curve shows that $I_{A}$ began to inactivate at $-83 \mathrm{mV}$ and was completely inactivated at $-45 \mathrm{mV}$. This fit generated the midpoint $\left(V_{1 / 2}\right)$ and slope factor $(k)$ as $-66 \pm 0.8$ and $4.9 \pm 0.3 \mathrm{mV}(n=6)$, respectively. $G, H$, The addition of AA did not alter the properties of steady-state inactivation because both initial and complete inactivation of the current were the same as for control conditions. $V_{1 / 2}$ and $k$ showed no significant differences from control conditions because these values were $-67.8 \pm 0.5$ and $5.4 \pm 0.5 \mathrm{mV}(n=6)$, respectively. 

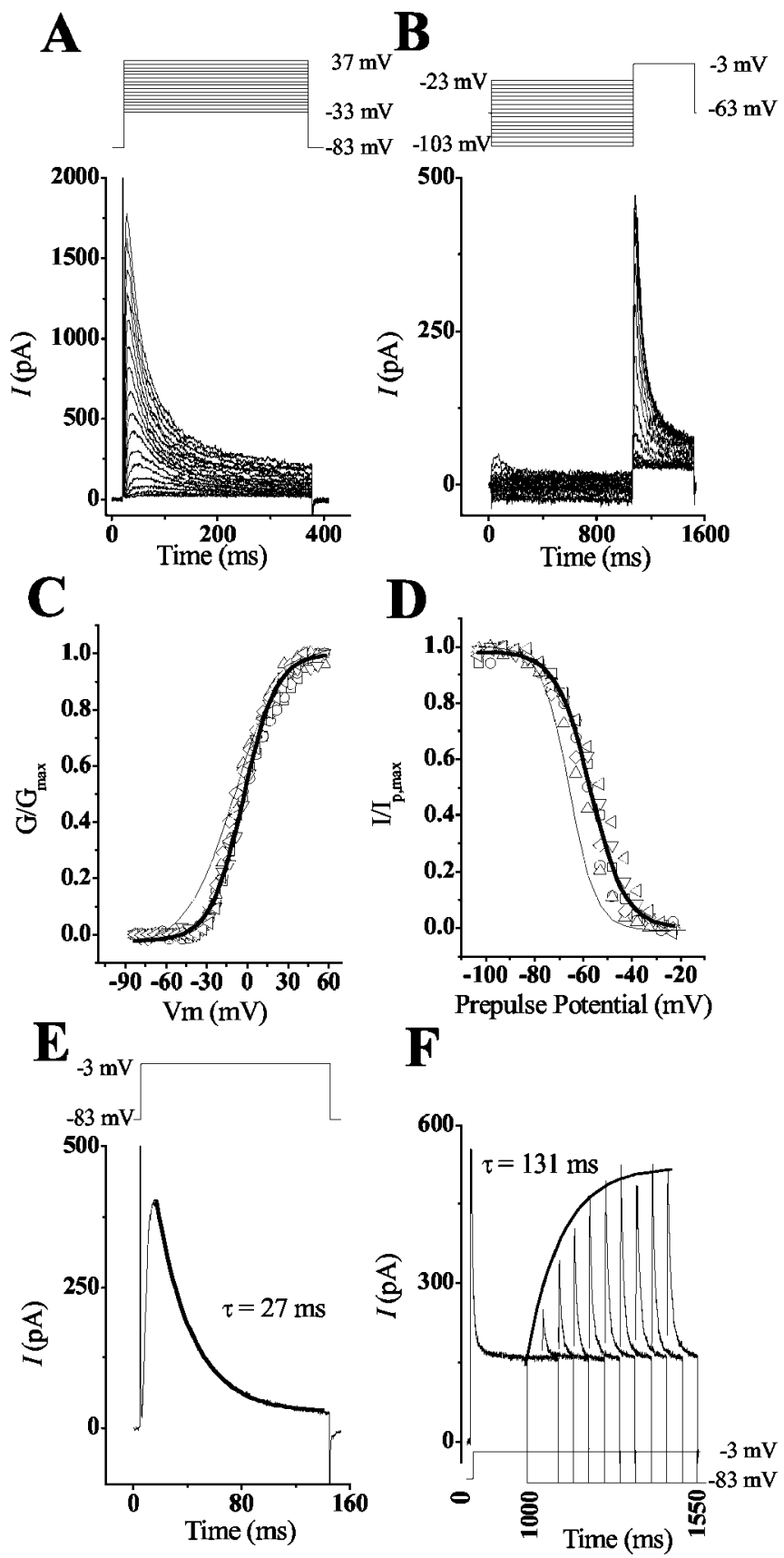

Figure 5. The activation and steady-state inactivation of cKv4.2 expressed in CHO cells differ from the kinetics in hair cells. $A, C$, Depolarization of transfected $\mathrm{CHO}$ cells elicited a transient voltage-dependent current that began to activate at $-35 \mathrm{mV}$ and was completely activated at $40 \mathrm{mV}$. To determine the conductance, the peak current amplitude was divided by the driving force across the membrane using the reversal potential of $-83 \mathrm{mV}$ (obtained from tail current measurements not shown). Conductance values were normalized to the maximal conductance and plotted against the membrane potential. The solid line was derived by fitting the data from these different cells to a Boltzmann equation (Fig. 3). From this fit, the midpoint $\left(V_{1 / 2}\right)$ and slope $(k)$ parameters were derived as $-2.8 \pm 0.7$ and $12.3 \pm 0.6 \mathrm{mV}$, respectively. For comparison of $\mathrm{CH} 0$ versus hair cell responses, the voltage - conductance fit from Figure $3 B$ (thin line) is superimposed on this plot. $B, D$, Steady-state inactivation properties of the transient current were determined by presenting a prepulse of $1 \mathrm{sec}$, at the given membrane potentials, followed by a test pulse of $-3 \mathrm{mV}$ for $450 \mathrm{msec}$. The peak current during the test pulse was normalized to the maximal current obtained after a prepulse of $-103 \mathrm{mV}$. The solid line was derived using a Boltzmann equation (Fig. 3). This fit generated midpoint $\left(V_{1 / 2}\right)$ and slope $(k)$ values of $-57.95 \pm 0.55$ and $-7.6 \pm 0.5 \mathrm{mV}$, respectively. For comparison of $\mathrm{CHO}$ versus hair cell responses, the steady-state inactivation fit from Figure $3 F$ (thin line) is superimposed on this plot. $E$, Plot of the response that was generated by depolarizing a $\mathrm{CHO}$ cell to $-3 \mathrm{mV}$ from a holding potential of $-83 \mathrm{mV}$. When these responses were fit with a single-order exponential,
Photometrix PXL video camera containing a $512 \times 512$ pixel CCD chip. Positive control sections consisted of cerebellum from C57BL/6 mice that were incubated with anti-Kv4.2 antiserum, whereas negative control sections were incubated in $2 \%$ goat serum in TPBS instead of primary antibody.

\section{Results}

\section{cDNA and deduced protein of cKv4.2}

The cloned cDNA of chick Kv4.2 (GenBank accession number AF075160) consists of 2314 bp, of which 1896 bp contain a single open reading frame, with 98 bp of $5^{\prime}$ untranslated and $320 \mathrm{bp}$ of $3^{\prime}$ untranslated sequence (Fig. 1). The deduced protein sequence contains 632 amino acids, and the predicted molecular mass of the primary translation product is $71 \mathrm{kDa}$. Similar to other $\mathrm{K}^{+}$ channel proteins (Butler et al., 1989), cKv4.2 has six hydrophobic domains (S1-S6) (Fig. 1), which are considered to be membranespanning regions. Joining segments S5 and S6 is the highly conserved region with a hairpin shape known as the H5 (Baldwin et al., 1991) or pore region. This hydrophobic loop, which has a crucial role in ion conduction (Kukuljan et al., 1995), extends from A-365 to G-383 in cKv4.2. The S4 region is a major component of the voltage sensor in $\mathrm{K}^{+}$channels (Chandy and Gutman, 1995), and in cKv4.2 it contains a string of positively charged residues. The deduced amino acid sequence of $\mathrm{cKv} 4.2$ reveals a number of potential biologically significant sites and signatures for posttranslational modification. All putative glycosylation sites, which are located in the $\mathrm{N}$ and $\mathrm{C}$ termini at Asn-46 and Asn-408, respectively, are intracellular according to current models of protein folding (Chandy and Gutman, 1995). These sites are unlike Shaker encoded proteins because Shal lacks the $\mathrm{N}$-linked glycosylation consensus site in the S1-S2 linker region, which is exposed to the extracellular side in most $\mathrm{K}^{+}$channels (Butler et al., 1989; Frech et al., 1989; Pak et al., 1991a). The cKv4.2 amino acid sequence shows potential cAMP- and cGMPdependent protein kinase phosphorylation sites in the N-terminal region. These sites regulate the inactivation kinetics as observed in fly (Shal accession number AAF49144), rat (Baldwin et al., 1991), and mouse (Pak et al., 1991b). A potential PKC site, which is highly conserved in $\mathrm{K}^{+}$channels (Chandy et al., 1995), is found at Thr-316 between the S4 and S5 region of cKv4.2. Other putative PKA and PKC sites are as marked in Figure 1. Among these are clustered or overlapping phosphorylation sites that may represent sites of interaction between different kinases in $\mathrm{cKv} 4.2$. Also, similar to mouse (Adams et al., 2000), cKv4.2 has potential sites that interact with the MAPK (mitogen-activated protein kinase), ERK (extracellular signal-related kinase), at amino acids 211-213 (Val Ser Pro), 517519 (His Ser Pro), 603-605 (Pro Thr Pro), 608-610 (Thr Thr Pro), and 617-619 (Glu Ser Pro).

The predicted amino acid alignment of $\mathrm{cKv} 4.2$ shows an identity of $94 \%$ when compared with rat (accession number AAB19939), human (accession number CAB56841), and mouse (accession number AAD16972) homologs (data not shown). Among Shal proteins, the homology across species extends

the rate of current inactivation ( $\tau=27 \mathrm{msec}$ ) did not differ significantly from that seen in hair cells. $F$, The recovery from inactivation for recombinant channels was longer than recovery for native channels. $\mathrm{CHO}$ cells were voltage clamped to $-83 \mathrm{mV}$ and depolarized to $-3 \mathrm{mV}$ for 1 sec to fully inactivate transient currents. A prepulse to $-83 \mathrm{mV}$ of increasing duration $(50 \mathrm{msec}$ intervals) was given to deinactivate the current, followed by a depolarizing test pulse to $-3 \mathrm{mV}$ to activate the deinactivated transient channels. The rate of recovery from inactivation was determined by plotting the peak $I_{A}$ generated against the prepulse duration. The solid line shows the curve fit generated for the responses using the equation described in Figure 4 . This fit generated the exponential time constant $\tau=131 \mathrm{msec}$. 

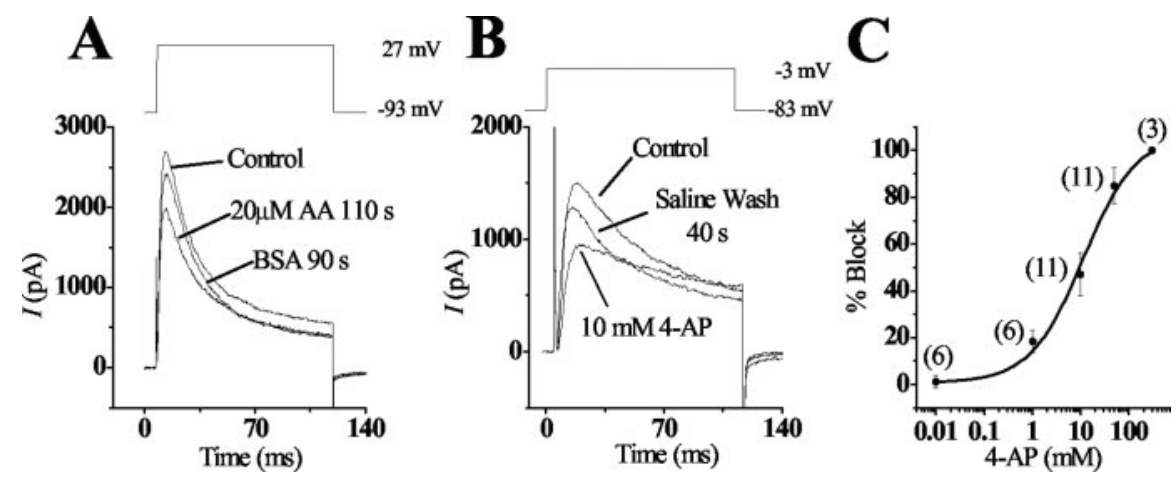

Figure 6. Effects of $\mathrm{AA}$ and 4-AP on heterologously expressed cKv4.2. A, The transient current generated in a CHO cell, by depolarizing the membrane to $27 \mathrm{mV}$ from a holding potential of $-93 \mathrm{mV}$, was partially blocked with $20 \mu \mathrm{m} \mathrm{AA}$. This block was reversed by washing the cell in $1 \mathrm{mg} / \mathrm{ml} \mathrm{BSA}$. B, The transient current generated in CHO cells was sensitive to 4-AP, as shown by a partial block with $10 \mathrm{~mm} 4-A P$ when the cell was depolarized to a membrane potential of $-3 \mathrm{mV}$ from a holding potential of -83 $\mathrm{mV}$. C, The dose-response relationship is plotted as the percentage of the transient current blocked by various concentrations of 4-AP. A curve fit was generated using the Michaelis-Menten equation, which revealed that half the channels were blocked with $11 \mathrm{~mm} 4-\mathrm{AP}(k=0.71)$. Numbers in parentheses indicate numbers of cells tested.

beyond the conserved domain to the $\mathrm{N}$ terminus. This result is in contrast to the sequence identity observed between members of the Shaker family of $\mathrm{K}^{+}$channels, which do not extend to the termini of the protein. In Shal, both the hydrophobic regions of S1-S6 and the hydrophilic linker regions separating them are highly conserved, as is the $\mathrm{S} 4$ membrane-spanning region (Fig. 1, amino acids Gly287-Phe301), which is thought to be the core of the voltage sensor in $\mathrm{K}^{+}$channels. In contrast, Shal members $\mathrm{Kv} 4.1,4.2$, and 4.3 differ at their C-terminal end. In comparison with cKv4.2, rabbit Kv4.3 (accession number AAF06021) has 19 additional amino acids inserted after amino acid 487 (i.e., chick aa 491) and mouse Kv4.1 (accession number A39372) has an additional 4 and 20 amino acids inserted after amino acids 522 and 619 , respectively.

\section{Hair cells express an AA-sensitive transient current}

The A-current described in the short hair cells of the chick was shown to be a 4-AP-sensitive channel (Murrow, 1994). In our search for the candidate gene that encodes this channel, $\mathrm{cKv} 4.2$ was isolated from a cDNA library of the chick cochlea. The observation that channels encoded by this gene are sensitive to AA prompted us to examine this current in the presence of this PUFA. The transient A-type current in isolated hair cells is activated when the cell is depolarized from a membrane potential of $-83 \mathrm{mV}$ (Fig. $2 A-C$ ) and inactivated when depolarized from a membrane potential of $-43 \mathrm{mV}$ (data not shown). The plots in Figure 2, $A$ and $B$, show difference curves, which were derived as outlined in Materials and Methods. Superfusion of the cell with 10,20 , or $30 \mu \mathrm{M}$ AA blocked $36.6 \pm 5.9 \%(n=5), 49.3 \pm 5.6 \%$ $(n=16)$, and $39 \pm 4.2 \%(n=14)$ of the maximum peak transient current after $126 \pm 16.4 \mathrm{sec}(n=23)$ (Fig. $2 A)$. To verify the AA effect, we used its nonmetabolic analog ETYA and showed that $40 \pm 6 \%(n=3)$ of the peak current was blocked with a concentration of $30 \mu \mathrm{M}$ (Fig. $2 \mathrm{~B}$ ). The same current was blocked by $97 \pm$ $2.5 \%(n=8)$ with $10 \mathrm{~mm} 4$-AP (Fig. $2 C)$, an amount equivalent to that predicted by the 4-AP dose-response curve obtained for $I_{\mathrm{A}}$ in short hair cells (Murrow, 1994).

We examined the voltage responses in the presence of AA and 4-AP because there were no data about the potential functional attributes of this channel. Figure $2 D$ shows a hair cell that was depolarized to $30 \mathrm{mV}$ from its resting potential $(I=0)$ of approximately $-50 \mathrm{mV}$, with a $40 \mathrm{pA}$ injection of current. This depolar- ization elicited a transient voltage response. Block of $I_{\mathrm{A}}$, with the addition of 20 $\mu \mathrm{M}$ AA, increased the amplitude of the voltage response significantly, although the cell did not repolarize. This effect was reversible by washing the cell with BSA. The rationale for the next experiment was based on findings that suggest that the large calyceal efferents, which innervate the short hair cells, hyperpolarize the cell; this condition is similar to what occurs with efferent stimulation of mammalian outer hair cells. Here, the premise was that at more negative holding potentials a greater number of A-channels are recruited to a closed state, and thus more would open after depolarization. Superfusing a hair cell with either $20 \mu \mathrm{M}$ AA or $10 \mathrm{~mm}$ 4-AP while depolarizing from a membrane potential of approximately $-80 \mathrm{mV}$ produced similar results; both drugs increased the amplitude and duration of the voltage response (Fig. $2 E, F$ ). Furthermore, unlike the experiment with the hair cell shown in Figure 2D, enough A-channels remained open during the block with AA or 4-AP that the cell partially repolarized after depolarization.

A study of the voltage-conductance relationship revealed that $I_{\mathrm{A}}$ was activated at -40 to $-50 \mathrm{mV}$, with half the channels active at $-9.7 \pm 1.3 \mathrm{mV}(n=10)$ and all channels active at potentials $>45 \mathrm{mV}$ (Fig. $3 \mathrm{~A}, \mathrm{~B}$ ). Hair cells, superfused with AA, showed no change in the voltage-conductance of activation: half-activation was measured at $-9.8 \pm 0.8 \mathrm{mV}$ (Fig. $3 C, D$ ). Measurements of the voltage dependency of inactivation revealed that $I_{\mathrm{A}}$ began to inactivate at $-83 \mathrm{mV}$, with half the channels inactive at $-66 \pm$ $0.8(n=6)$ and all channels inactive at $-45 \mathrm{mV}$ (Fig. $3 E, F)$. Similar measurements made in the presence of AA produced no significant shifts because half of the channels were inactivated at $-67.8 \pm 0.5 \mathrm{mV}(n=6)$ (Fig. $3 G, H)$. In contrast, the time dependency of inactivation was affected by AA. The difference curves show that cells depolarized to a membrane potential of -3 $\mathrm{mV}$ from a holding potential of -83 or $-93 \mathrm{mV}$, in normal saline, had an average inactivation time constant of $\tau=23.1 \pm$ $3.3 \mathrm{msec}(n=11)$ (Fig. $4 A)$. When the cell was superfused with $\mathrm{AA}$, however, the rate of inactivation decreased approximately twofold $(\tau=12.1 \pm 3.6 ; n=11)$ (Fig. $4 A$ ). Removal of inactivation or deinactivation was time dependent $(\tau=15 \pm 0.7 \mathrm{msec}$; $n=3$ ) and required membrane potentials more negative than $-80 \mathrm{mV}$ (Fig. $4 \mathrm{~B}$ ). This time constant was significantly different from that reported for the recombinant channel.

\section{Kinetics of cKv4.2 in CHO cells differ from those in hair cells} Previous studies showed differences in the kinetics and pharmacology of the recombinant $\alpha$-subunit of Kv 4 subfamily members expressed in heterologous expression systems versus those expressed in native cells (Rudy et al., 1988; Chabala et al., 1993; Serõdio et al., 1996). Recordings from CHO cells transfected with cKv4.2 cDNA revealed voltage-gated currents that were rapidly activating, followed by inactivation (Fig. $5 A, B$ ). Depolarization from a holding potential of $-93 \mathrm{mV}$ to a membrane potential of $57 \mathrm{mV}$ elicited a current that activated at $-38 \mathrm{mV}$ and had a mean activation time constant of $3.1 \pm 0.9 \mathrm{msec}(n=9)$. Half of the A-channels were activated at a membrane potential of $-3 \pm 0.7$ $\mathrm{mV}$, whereas all channels were activated at potentials $>45 \mathrm{mV}$ 
(Fig. 5C). Consequently, the halfactivation voltage of $I_{\mathrm{A}}$ in $\mathrm{CHO}$ cells was 6 $\mathrm{mV}$ more positive than half-activation in hair cells. Similar differences were found when examining the inactivating steadystate properties of the recombinant channels. During depolarization, $I_{\mathrm{A}}$ began to inactivate within $10 \mathrm{msec}$ of activation and showed a dependency on both time and voltage. Measurements of the voltage dependency of inactivation showed half the channels inactivated at $-58 \mathrm{mV} \pm 0.6$ $(n=6)$ (Fig. $5 B, D)$, whereas all channels inactivated at membrane potentials greater than $-30 \mathrm{mV}$. Thus, steady-state inactivation in $\mathrm{CHO}$ cells was shifted by $\sim 8 \mathrm{mV}$ in the positive direction relative to inactivation in hair cells. In contrast to native channels, measurements of the time dependency of inactivation in recombinant channels showed no significant differences. When $\mathrm{CHO}$ cells were depolarized to a potential of -3 or $-27 \mathrm{mV}$ from a holding potential of -83 or $-93 \mathrm{mV}$, the resulting inactivation time constant was similar to that measured in native cells $(\tau=30.7 \pm 3 \mathrm{msec} ; n=12$ ) (Fig. $5 E)$. Unlike hair cells, this time constant did not shift significantly in the presence of AA $(\tau=28 \pm 1.5 \mathrm{msec} ; n=7)$, suggesting that there was an absence of a subunit such as $\mathrm{K}^{+}$channel interacting protein (KChIP), which can increase the rate of inactivation (Holmqvist et al., 2001). Finally, deinactivation of the recombinant channels was both voltage and time dependent and showed a significant shift relative to native channels (Fig. 5F). Recovery from inactivation required membrane potentials more negative than $-83 \mathrm{mV}$; however, the rate of recovery was approximately ninefold greater $(131 \pm 4 \mathrm{msec} ; n=4)$ than the rate measured in hair cells.

Pharmacological studies of cKv4.2 expression in $\mathrm{CHO}$ cells revealed that, similar to native channels, the recombinant channel was sensitive to both AA and 4-AP. The addition of $20 \mu \mathrm{M}$ AA blocked $68 \pm 33 \%(n=5)$ of the maximum peak A-current after $355 \pm$ $188 \mathrm{sec}(n=5)$ (Fig. $6 A)$. Compared with the native channel, the recombinant channel appeared less sensitive in terms of the length of time to reach maximal block; however, similar to the native channel, AA block in $\mathrm{CHO}$ cells was reversed when washed with $1 \mathrm{mg} / \mathrm{ml}$ BSA. Addition of 4-AP in concentrations ranging from 0.01 to $300 \mathrm{~mm}$ showed that half of the channels were blocked at $11 \mathrm{~mm}$ (Fig. 6B,C). This result differs substantially from the reported half-block value $(0.45 \mathrm{~mm})$ in short hair cells (Murrow, 1994).

\section{cKv4.2 transcript and protein expression in cochlea}

We were interested in localizing mRNA and protein expression of this channel in the cochlea to further verify the findings from the library screening, in light of the discrepancy between the kinetics

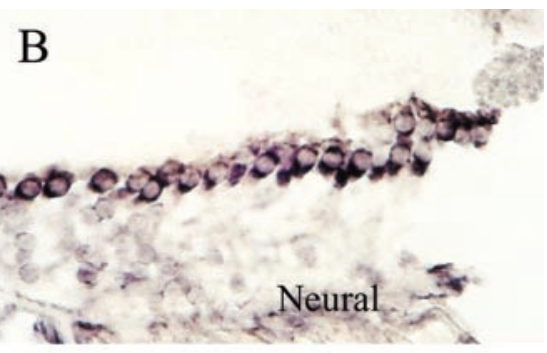

$\mathrm{D}$

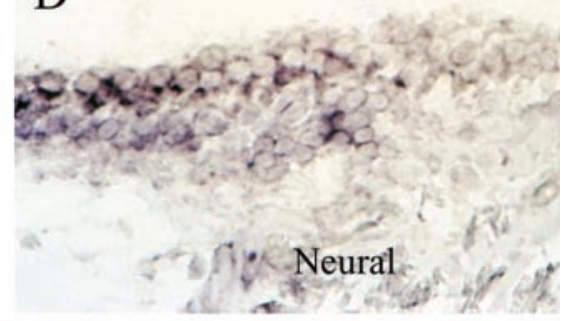

Abneural $+$
Neural

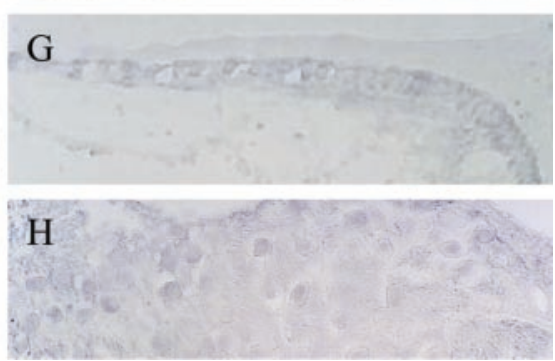

Figure 7. Distribution of cKv4.2 mRNA as revealed by in situ hybridization in a 2-week-old posthatched chick. A, B, Photomicrographs of the same cross section, taken from proximal regions of the chick cochlea, revealed cKv4.2 transcription in hair cells re there is a gradation from short to tall hair cells across the width of the epithelium, cKv4.2 was transcribed only in hair cells (he same section as in ( showed no signal. These cells are positioned slightly Additionally, CKv4.2 mRNA was found in the soma of the cochlear ganglion cells. G. H, In comparison, sections treated with cKv4.2 sense probe showed an absence of signal in both the sensory epithelium $(G)$ and ganglion cells $(H)$. Sections of cochlea shown are $\sim 1700 \mu \mathrm{m}(A, B), 500 \mu \mathrm{m}(C, D), 120 \mu \mathrm{m}(E), 1700 \mu \mathrm{m}(F)$, and $1500 \mu \mathrm{m}(G, H)$ from the distal tip of the epithelium. Scale bar: (in $A) A-D, 25 \mu \mathrm{m} ; E, 18 \mu \mathrm{m} ; F, 45 \mu \mathrm{m} ; G, 30 \mu \mathrm{m} ; H, 50 \mu \mathrm{m}$.

of native and recombinant channels. Results from studies using in situ hybridization showed that the overall pattern was that of an expression gradient across the width and length of the cochlea. Transcription of cKv4.2 was found in all cross sections that contained short and intermediate hair cells but absent in cross sections that contained tall hair cells. In proximal regions, short hair cells are positioned across the width of the cochlea; in more distal regions there is a gradation in length from short to intermediate to tall hair cells (i.e., abneural to neural). In the most distal regions, tall hair cells span the width of the sensory epithelium. Thus, at the proximal end of the cochlea, cKv4.2 mRNA was expressed in all hair cells (Fig. $7 A, B$ ), whereas in more distal regions, mRNA was present in intermediate and short hair cells and absent from tall hair cells (Fig. $7 C, D$ ). In the most distal regions, $\mathrm{cKv} 4.2$ transcription was absent in all hair cells because 

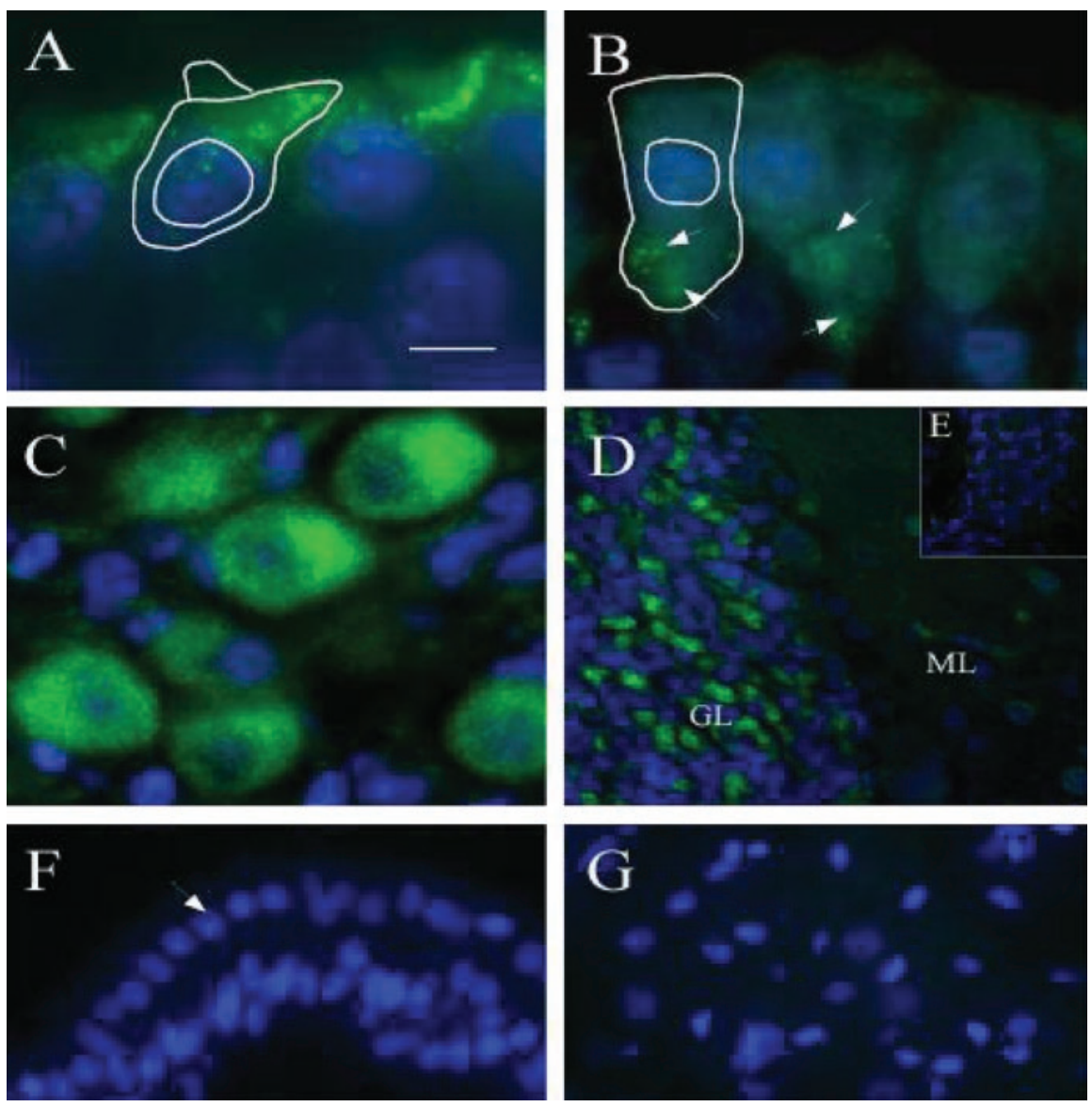

Figure 8. Distribution of Kv4.2 channel protein as revealed by FITC immunostaining in cross sections of the cochlea from a PD19 chick. A, Immunostaining occurred in hair cells that were short to intermediate in length. Each cell showed intense FITC staining that was localized above the nucleus and on the side of the cell facing the neural part of the cochlea. A short hair cell with its nucleus and stereocilia is outlined in white. $B$, In contrast, tall hair cells found near the neural edge showed no distinct immunostaining in the cell; however, some tall hair cells showed punctate immunostaining at the base that was localized to small bouton nerve endings innervating these cells (arrows). A tall hair cell with its nucleus is outlined in white. C, Immunoreactivity occurred in the soma of the cochlear ganglion cells. D, A positive control section from the mouse cerebellum showed immunostaining in the glomeruli of the granular cell layer (GL) and not the molecular layer (ML). $E-G$, Immunoreactivity was absent from negative controls as revealed in cross sections of tissue from mouse cerebellum, cochlear epithelium (arrow indicates hair cell nuclei), and cochlear ganglion cells, respectively. All sections were DAPI stained to reveal the nucleus of the cell. Sections of cochlea shown are approximately $2100 \mu \mathrm{m}(A), 1100 \mu \mathrm{m}(B), 1800 \mu \mathrm{m}(C), 500 \mu \mathrm{m}(F)$, and $1300 \mu \mathrm{m}(G)$ from the distal tip of the cochlear epithelium. Scale bar: (in $A) A, B, 5 \mu \mathrm{m} ; C, 10 \mu \mathrm{m} ; D, 25 \mu \mathrm{m} ; E, 120 \mu \mathrm{m} ; F, 20 \mu \mathrm{m} ; G, 6 \mu \mathrm{m}$.

they are all tall (Fig. 7E). Also, cKv4.2 was transcribed in the cochlear ganglion cells (Fig. $7 F$ ). No signal was detected in either the epithelium or the ganglion cells (Fig. 7G,H) when the sense probe was used.

Immunofluorescent staining for $\mathrm{cKv} 4.2$ protein was observed in the distal half of the cochlea in short and intermediate hair cells, which are located on the abneural side (Fig. $8 \mathrm{~A}$ ). This immunoreactivity was localized to an area above the nucleus on the neural side of the cell, a region extraneous to the area of contact made by the various nerve terminals that synapse on these cells. In comparison, tall hair cells showed no immunofluorescence. Bouton terminals innervating some tall hair cells were immunoreactive (Fig. $8 \mathrm{~B}$ ). Additionally, immunoreactivity was found in the ganglion cell soma (Fig. $8 C$ ). Positive controls, using sections from mouse cerebellum, had reactions localized to the cerebellar islands (glomeruli) of the granular cell layer (Fig. 8D). This outcome was as expected when using anti-Kv4.2 antiserum on this tissue (Shibata et al., 1999). Negative controls, using mouse cerebellum and chick cochlea and ganglion, showed only nonspecific immunoreactivity (Fig. $8 E-G$ ).
Thus far, the earliest whole-cell tightseal recordings of $I_{\mathrm{A}}$ in the cochlea suggest its presence as early as E10-12 (Griguer and Fuchs, 1996). An initial developmental map of expression was produced by examining mRNA expression, because we are interested in the regulatory mechanisms of channel development in the cochlea. RT-PCR products obtained from cochlear tissues, aged E3 to PD1, revealed that cKv4.2 was expressed as early as E3 and continued its expression throughout the embryonic period (Fig. 9). Moreover, transcription continued on PD1, although expression was lower than during the embryonic period. Although this outcome was not measured quantitatively, it was repeatable over several experiments. Dissection of the cochlear duct into its various parts showed that transcription was relegated to the cochlear epithelium and ganglion, whereas expression was very low or absent from the lagena and tegmentum vasculosum.

\section{Discussion}

The primary findings of this study are as follows. (1) The transient A-type channel in hair cells is AA sensitive and encoded by a member of the Shal subfamily, Kv4.2; transcription of this gene is cell specific, appears early in development, and is found only in short and intermediate hair cells of the adult. (2) The kinetics of the native channel differed from those of recombinant $\mathrm{Kv} 4.2$ expressed in $\mathrm{CHO}$ cells, suggesting the presence of an accessory subunit in hair cells. (3) AA alters the voltage response in a manner similar to that of 4-AP by increasing the amplitude and duration; moreover, the effects on the transient current appear to be direct because they are mimicked by the nonmetabolizable analog ETYA.

Our data reveal a match between the transcript and protein expression studies of Kv4.2 and previous recordings (Murrow, 1994) made from intermediate and short hair cells in the adult. Transcription was absent from tall hair cells and distal regions of the cochlea in which previous recordings showed a decrease or absence of $I_{\mathrm{A}}$. Immunostaining revealed that protein expression was clustered toward the apical ridge on one side of the hair cell. This clustering is outside the afferent and efferent synaptic zones (Fischer, 1992), thereby placing these channels outside the sphere of direct junctional activity; however, they are in a suitable location for modulating electrical signals originating at the efferent terminals and the transduction site, the stereocilia. Additionally, A-channel transcription and protein expression occurred in the soma of the cochlear ganglion cells. The localization of Kv4.2 to the short and intermediate hair cells and to cochlear ganglion cells further supports the initial observation that this channel is typically found at postsynaptic sites (Sheng et al., 1992).

Transcript expression of cKv4.2 on E3 differed significantly from the previously reported acquisition of $I_{\mathrm{A}}$ on E10-12 
$\mathbf{A}$

\section{cKv4.2}
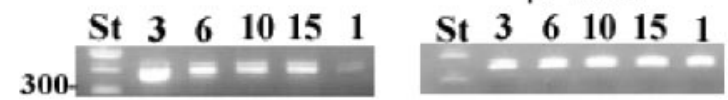

B

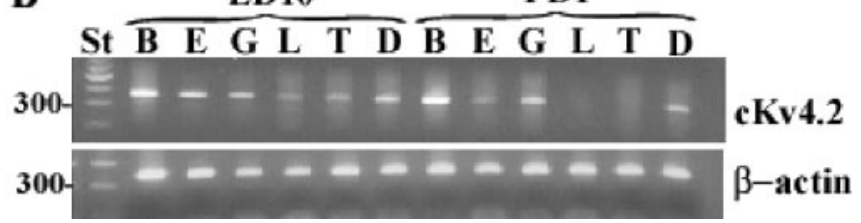

Figure 9. Results from RT-PCR experiments show the 250 bp expression products for cKv4.2 during development. $A$, Lanes show cKv4.2 expression on E3, 6, 10, and 15, and PD1. Tissues on E3 consisted of the otocyst, which included the presumptive epithelia, as well as the adjoining, differentiating ganglion cells. Tissues at other ages were obtained from the entire cochlear duct and included ganglion, phalangeal, and tegmentum vasculosum cells, as well as receptor and supporting cells of the cochlear and lagenar sensory epithelia. B, Expression of mRNA on E10 and PD1 was compared using tissue from the brain and various parts of the cochlear duct. On E10, cKv4.2 mRNA was expressed in brain (B), sensory epithelium of the cochlea (E), ganglion cells $(G)$, lagenar epithelium (L), tegmentum vasculosum $(T)$, and the cochlear duct as a whole (D). On PD1, mRNA expression was absent from cells of the lagena and tegmentum vasculosum. $\beta$-Actin (246 bp) served as a positive control in all experiments. Products were absent from experiments without reverse trancriptase (data not shown). The standard (St) consisted of a 100 bp DNA ladder.

(Sokolowski et al., 1993; Griguer and Fuchs, 1996). On E3, the hair and supporting cells of the presumptive sensory epithelia are undifferentiated, as are the various end-organs. Presently, the evidence from whole-cell tight-seal recordings suggests that ionic currents are absent from these presumptive cells (Sokolowski et al., 1993); however, recordings have been made from only a few cells relative to the thousands present at this stage (Sokolowski et al., 1999). Moreover, this amplified expression suggests that mRNA precedes protein expression or the expressed transcripts may originate with the ganglion cells, in which we have recorded A-currents as early as E5-6 (our unpublished data). These cells abut the medial-ventral wall of the otocyst on E3 and can adhere to the otocyst during the harvesting of tissues.

The kinetic properties and the AA sensitivities were different between the recombinant $\alpha$-subunit, cKv4.2, and the A-channel in hair cells. These differences suggest the presence of an accessory subunit in hair cells. The characteristics of the recombinant cKv4.2 $\alpha$-subunit mirror various Kv4.2 subunits expressed alone (Rudy et al., 1988; Chabala et al., 1993; Serõdio et al., 1996). For example, rat Shal1 (i.e., Kv4.2), expressed in oocytes, revealed half-activation and -inactivation values of -4 and $-48 \mathrm{mV}$, respectively (Baldwin et al., 1991), whereas Kv4.3 expressed in CHO-K1 cells had similar values of -7 and $-51 \mathrm{mV}$ (Singleton et al., 1999). Also, the half-block concentrations of 4-AP for recombinant Shal channels are greater than those reported for the native channel (Serõdio et al., 1996; Faivre et al., 1999). Initially, investigators cotransfected Shal mRNA with low molecular weight molecules from brain to mimic the expression, kinetics, and pharmacology of the native channel (Rudy et al., 1988; Chabala et al., 1993; Serõdio et al., 1996). More recently, molecules identified as accessory subunits include DPPX (a protein structurally related to the dipeptidyl amino peptidase and cell adhesion protein $\mathrm{CD} 26$ ), which can reproduce the properties of native A-channels when combined with recombinant channels (Nadal et al., 2003). Other ancillary subunits include KChIPs and the neuronal calcium sensor protein 1 (NCS1), which alter inactivation, accelerate the rate of recovery from inactivation, shift the voltage dependence of steady-state inactivation, and increase the sensitivity to AA (An et al., 2000; Holmqvist et al., 2001; Guo et al., 2002; Scannevin et al., 2004; Zhou et al., 2004). In hair cells, the acquisition of such a subunit may reveal why $I_{\mathrm{A}}$, during early development shows no difference in sensitivity to TEA or 4-AP, as does its adult counterpart (Griguer and Fuchs, 1996), whereas $I_{\mathrm{A}}$ is sensitive to 4-AP and nonsensitive to TEA. Furthermore, the acquisition of ancillary subunits during development in hair cells may not only alter A-channel characteristics, but may regulate expression because KChIP and DPPX increase the density of A-channels (Guo et al., 2002; Zhou et al., 2004).

The striking aspect of the short hair cells is that they are innervated only by efferents (Fischer 1992). A-channels conduct the largest fast-activating current, yet remain in an inactivated state at the average resting potential $(-46 \mathrm{mV})$ of short hair cells (Murrow, 1994). Consequently, $I_{\mathrm{A}}$ activation is closely linked with the efferents, because they hyperpolarize these cells, and to bending of the stereocilia in the hyperpolarizing direction. Our data show that at more positive resting potentials, the voltage response was small and transient. With the addition of AA, the voltage amplitude increased and its shape was altered, depending on the resting potential of the cell. On depolarization from more positive potentials, the amplitude of the voltage response increased, driven by the influx of $\mathrm{Ca}^{2+}$ through L-type channels, which predominate in these hair cells (Fuchs et al., 1990; Zidanic and Fuchs, 1995). This large influx of $\mathrm{Ca}^{2+}$ and the sustained depolarization would probably damage the cells, because similar responses were reported when $\mathrm{K}^{+}$channels in hippocampal cells were blocked with 4-AP (Colbert and Pan, 1999). Thus, the activation of even a few A-channels may dampen this effect. At more negative holding potentials, a greater number of A-channels are moved from the inactive state to the closed state. In the presence of AA, depolarizations from more negative resting potentials produced an increase in both the amplitude and duration of the transient voltage response. Here, there was a partial repolarization of the cell to the resting potential. It is against this background that responses to a sound stimulus may be played out. Although $I_{\mathrm{A}}$ would not be active at most auditory frequencies as a result of a positive shift in the DC potential (Holton and Weiss, 1983), once efferents hyperpolarize the cell, the A-channel may act as a current shunt and alter the membrane time constant, thereby dampening or increasing the overall response, depending on its relative speeds of activation and deactivation. Modeling of $\mathrm{K}^{+}$currents, such as $I_{\mathrm{K}}$, shows that they can act as high-pass filters (Hutcheon and Yarom, 2000).

Evidence suggests that the cochlear amplifier in lower vertebrates lies in the stereocilia (for review, see Hudspeth et al., 2000; Manley, 2000), because presently there is no evidence for motility along the basolateral walls of hair cells in these vertebrates, including chick (He et al., 2003). The stereocilia in chick short hair cells show mechanically evoked oscillations of up to $200 \mathrm{~Hz}$ (Hudspeth et al., 2000), and spontaneous oscillations in anurans occur at frequencies of 5-40 Hz (Martin and Hudspeth, 1999). $I_{\mathrm{A}}$ may modulate potential signals generated at these lower frequencies in addition to the slow postsynaptic signals generated by efferent stimulation. How the interplay between these signals is processed and the possibilities of modulating motility via efferent stimulation are questions to consider for future experimentation.

How might the AA cascade be initiated given the localization of the A-channel toward the apex of the hair cell? Responses to AA and its nonmetabolizing analog ETYA suggest that the effect of AA in hair cells is direct. Similar conclusions were drawn from studies of Kv4 members using cell-free attached patches from hippocampal pyramidal cells (Keros and McBain, 1997) and 
oocytes (Villarroel and Schwarz, 1996) as well as whole-cell clamp recordings of oocytes (Holmqvist et al., 2001). ETYA does not act as a substrate for metabolites such as lipoxygenase, cyclooxygenase, or epoxygenase (Tobias and Hamilton, 1979). Also, the results argue against phosphorylation, because AA was readily washed out and did not require a phosphatase; however, we cannot rule out the role of intracellular $\mathrm{Ca}^{2+}$, because $\mathrm{Ca}^{2+}$ hydrolyzes AA-containing phospholipids by recruiting cytosolic phospholipase A2 (Piomelli, 1993). Chick hair cells release intracellular $\mathrm{Ca}^{2+}$ after cholinergic stimulation at both the apical and basal poles (Shigemoto and Ohmori 1990). Such a release could follow efferent stimulation because hyperpolarization is a function of cholinergic stimulation of receptors found on the short hair cells (Fuchs and Murrow, 1992). More recently, studies of outer hair cells in guinea pig attribute the intracellular stores of $\mathrm{Ca}^{2+}$ to Hensen's bodies (Lim, 1986), which consist of tubulovesicular and cisternal endoplasmic reticulum and densely packed mitochondria (Mammano et al., 1999). This structure lies below the cuticular plate and releases $\mathrm{Ca}^{2+}$ through inositol phosphate gating after extracellular ATP stimulation; however, additional studies are needed to identify potential sources in chick hair cells.

\section{References}

Adams JP, Anderson AE, Varga AW, Dinely KT, Cook RG, Pfaffinger PJ, Sweatt JD (2000) The A-type potassium channel Kv4.2 is a substrate for the mitogen-activated protein kinase ERK. J Neurochem 75:2277-2287.

An W, Bowlby MR, Betty M, Cao J, Li H-P, Mendoza G, Hinson JW, Mattsson KI, Strassle BW, Trimmer JS (2000) Modulation of A-type potassium channels by a family of calcium sensors. Nature 403:553-556.

Baldwin TJ, Tsaur ML, Lopez GA, Jan YN, Jan LY (1991) Characterization of a mammalian cDNA for an inactivating voltage-sensitive $\mathrm{K}^{+}$channel. Neuron 7:471-483.

Butler A, Wei AG, Baker K, Salkoff L (1989) A family of putative potassium channel genes in Drosophila. Science 243:943-947.

Chabala LD, Bakry N, Covarrubias M (1993) Low molecular weight poly $(\mathrm{A})+$ mRNA species encode factors that modulate gating of nonShaker A-type $\mathrm{K}^{+}$channel. J Gen Physiol 4:713-728.

Chandy CK, Gutman GA (1995) Voltage-gated potassium channel genes. In: Handbook of receptors and channels: ligand- and voltage-gated ion channels (North RA, ed), pp 1-71. Boca Raton, FL: CRC.

Colbert CM, Pan E (1999) Arachidonic acid reciprocally alters the availability of transient and sustained dendritic $\mathrm{K}^{+}$channels in hippocampal CA1 pyramidal neurons. J Neurosci 19:8163-8171.

Connor JA, Stevens CF (1971) Voltage clamp studies of a transient outward membrane current in gastropod neural somata. J Physiol (Lond) 213:21-30.

Daut J (1973) Modulation of the excitatory synaptic response by fast transient $\mathrm{K}^{+}$current in snail neurones. Nat New Biol 246:193-196.

Denson DD, Worrell RT, Middleton P, Eaton DC (1999) $\mathrm{Ca}^{2+}$ sensitivity of BK channels in GH3 cells involves cytosolic phospholipase A2. Am J Physiol 276:C201-C209.

Eatock RA, Hutzler MJ (1992) Ionic currents of mammalian vestibular hair cells. Ann NY Acad Sci 656:58-74.

Faivre J-F, Calmels TPG, Rouanet S, Javré J-L, Cheval B, Bril A (1999) Characterisation of Kv4.3 in HEK293 cells: comparison with the rat ventricular transient outward potassium current. Cardiovasc Res 41:188-199.

Fischer FP (1992) Quantitative analysis of the innervation of the chicken basilar papilla. Hear Res 61:167-178.

Frech GC, Van Dongen AM, Schuster G, Brown AM, Joho RH (1989) A novel potassium channel with delayed rectifier properties isolated from rat brain by expression cloning. Nature 340:642-645.

Fuchs PA (1992) Ionic currents in cochlear hair cells. Prog Neurobiol 39:493-505.

Fuchs PA, Evans MG (1990) Potassium currents in hair cells isolated from the cochlea of the chick. J Physiol (Lond) 429:529-551.

Fuchs PA, Murrow BW (1992) Cholinergic inhibition of short (outer) hair cells of the chick's cochlea. J Neurosci 12:800-809.

Fuchs PA, Sokolowski BHA (1990) The acquisition during development of
Ca-activated potassium currents by cochlear hair cells of the chick. Proc R Soc Lond B Biol Sci 241:122-126.

Fuchs PA, Evans MG, Murrow BW (1990) Calcium currents in hair cells isolated from the cochlea of the chick. J Physiol (Lond) 429:553-568.

Griguer C, Fuchs PA (1996) Voltage-dependent potassium currents in cochlear hair cells of the embryonic chick. J Neurophysiol 75:508-513.

Guo W, Malin SA, Johns DC, Jeromin A, Nerbonne JM (2002) Modulation of Kv4-encoded $\mathrm{K}^{+}$currents in the mammalian myocardium by neuronal calcium sensor-1. J Biol Chem 277:26436-26443.

He DZ, Beisel KW, Chen L, Ding DL, Jia S, Fritzsch B, Salvi R (2003) Chick hair cells do not exhibit voltage-dependent somatic motility. J Physiol (Lond) 546:511-520.

Holmqvist MH, Cao J, Knoppers MH, Jurman ME, Distefano PS, Rhodes KJ, Xie Y, An FW (2001) Kinetic modulation of Kv4-mediated A-current by arachidonic acid is dependent on potassium channel interacting proteins. J Neurosci 21:4154-4161.

Holton T, Weiss TF (1983) Receptor potentials of lizard cochlear hair cells with free-standing stereocilia in response to tones. J Physiol (Lond) 345:202-240.

Hudspeth AJ, Choe Y, Mehta AD, Martin P (2000) Putting ion channels to work: mechanoelectrical transduction, adaptation, and amplification by hair cells. Proc Natl Acad Sci USA 97:11765-11772.

Hutcheon B, Yarom Y (2000) Resonance, oscillation and the intrinsic frequency preferences of neurons. Trends Neurosci 23:216-222.

Kaczmarek LK, Strumwasser F (1984) A voltage-clamp analysis of currents underlying cyclic AMP-induced membrane modulation in isolated peptidergic neurons of Aplysia. J Neurophysiol 52:340-349.

Keros S, McBain CJ (1997) Arachiconic acid inhibits transient potassium currents and broadens action potentials during electrographic seizures in hippocampal pyramidal and inhibitory interneurons. J Neurosci 17:3476-3487.

Knepel W, Schoefl C, Goetz DM (1988) Arachidonic acid elevates cytosolic free calcium concentration in rat anterior pituitary cells. Arch Pharmacol 338:303-309.

Krutetskaia ZI, Lebedev OE, Krutetskaia NI, Kurilova LS (2001) Effect of arachidonic acid and other fatty acids on the intracellular calcium concentration and calcium signaling in peritoneal macrophages. Tsitologiia 43:1051-1060.

Kukuljan M, Labarca P, Latorre R (1995) Molecular determinants of ion conduction and inactivation in $\mathrm{K}^{+}$channels. Am J Physiol 268:C535-C556.

Kyte J, Doolittle RF (1982) A simple method for displaying the hydropathic character of a protein. J Mol Biol 157:105-132.

Lim DJ (1986) Functional structure of the organ of Corti: a review. Hear Res 22:117-146.

Mammano F, Frolenkov GI, Lagostena L, Belyantseva IA, Kurc M, Dodane V, Colavita A, Kachar B (1999) ATP-induced $\mathrm{Ca}^{2+}$ release in cochlear outer hair cells: localization of an inositol triphosphate-gated $\mathrm{Ca}^{2+}$ store to the base of the sensory hair cell bundle. J Neurosci 19:6918-6929.

Manley GA (2000) Cochlear mechanisms from a phylogenetic viewpoint. Proc Natl Acad Sci USA 97:11736-11743.

Martin P, Hudspeth AJ (1999) Active hair-bundle movements can amplify a hair cell's response to oscillatory mechanical stimuli. Proc Natl Acad Sci USA 96:14306-14311.

McPhail MC, Clayton CC, Snyderman R (1984) A potential second messenger role for unsaturated fatty acids: activation of $\mathrm{Ca}^{2+}$-dependent protein kinase. Science 224:622-625.

Meves H (1994) Modulation of ion channels by arachidonic acid. Prog Neurobiol 43:175-186.

Murrow B (1994) Position-dependent expression of potassium currents by chick cochlear hair cells. J Physiol (Lond) 480.2:247-259.

Nadal M, Ozaita A, Amarillo Y, Vega-Saenz de Miera E, Ma Y, Mo W, Goldberg EM, Misumi Y, Ikehara Y, Neubert TA, Rudy B (2003) The CD26related dipeptidyl aminopeptidase-like protein DPPX is a critical component of neuronal A-type $\mathrm{K}^{+}$channels. Neuron 37:449-461.

Needleman P, Turk J, Jakschik BA, Morrison AR, Lefkowith JB (1986) Arachidonic acid metabolism. Annu Rev Biochem 55:69-102.

Neher E (1971) Two fast transient current components during voltage clamp on snail neurons. J Gen Physiol 58:36-53.

Pak MD, Baker K, Covarrubias M, Butler A, Ratcliffe A, Salkoff L (1991a) $\mathrm{mShal}$, a subfamily of A-type $\mathrm{K}+$ channel cloned from mammalian brain. Proc Natl Acad Sci USA 88:4386-4390.

Pak MD, Covarrubias M, Ratcliffe A, Salkoff L (1991b) A mouse brain ho- 
molog of the Drosophila Shab $\mathrm{K}^{+}$channel with conserved delayedrectifier properties. J Neurosci 11:869-880.

Piomelli D (1993) Arachidonic acid in cell signaling. Curr Opin Cell Biol 5:274-280.

Rogawski MA, Beinfeld MC, Hays SE, Hokfelt T, Skirboll LR (1985) Cholecystokinin and cultured spinal neurons. Immunohistochemistry, receptor binding, and neurophysiology. Ann NY Acad Sci 448:403-412.

Rudy B, Hoger JH, Lester HA (1988) At least two mRNA species contribute to the properties of rat brain A-type potassium channels expressed in Xenopus oocytes. Neuron 1:649-658.

Scannevin RH, Wang K, Jow F, Megules J, Kopsco DC, Edris W, Carroll KC, Lü Q, Xu W, Xu Z, Katz AH, Olland S, Lin L, Taylor M, Stahl M, Malakian K, Somers W, Mosyak L, Bowlby MR, Chanada P, et al. (2004) Two $\mathrm{N}$-terminal domains of $\mathrm{Kv} 4 \mathrm{~K}^{+}$channels regulate binding to and modulation by KChIP1. Neuron 41:587-598.

Serõdio P, Kentros C, Rudy B (1996) Identification of molecular components of A-type channels activating at subthreshold potentials. J Neurochem 72:1516-1529.

Sheng M, Meei-Ling T, Jan YN, Jan LY (1992) Subcellular segregation of two A-type $\mathrm{K}^{+}$channel proteins in rat central neurons. Neuron 9:271-284.

Shibata R, Wakanozo Y, Nakahira K, Trimmer JS, Ikenaka K (1999) Expression of Kv4.2 genes in developing cerebellar granule cells. Dev Neurosci 21:87-93.

Shigemoto T, Ohmori H (1990) Muscarinic agonists and ATP increase the intracellular $\mathrm{Ca}^{2+}$ concentration in chick cochlear hair cells. J Physiol (Lond) 420:127-148.

Singleton CB, Valenzuela SM, Walker BD, Tie H, Bursill JA, Qiu MR, Breit
SN, Campbell TJ (1999) Blockade by N-3 polyunsaturated fatty acids of the Kv4.3 current stably expressed in Chinese hamster ovary cells. Br J Pharmacol 127:941-948.

Sokolowski BHA, Cunningham AM (1996) Sensory cells of the chick cochlea express synaptophysin. Neurosci Lett 216:89-92.

Sokolowski BHA, Cunningham AM (1999) Patterns of synaptophysin expression during inner ear development in the chicken. J Neurobiol 38:46-64.

Sokolowski BHA, Stahl LM, Fuchs PA (1993) Morphological and physiological development of vestibular hair cells in the organ-cultured otocyst of the chick. Dev Biol 155:134-146.

Sokolowski BHA, Csus J, Hafez OI, Haggerty HS (1999) Neurotrophic factors modulate hair cells and their potassium currents in chick otocyst explants. Eur J Neurosci 11:682-690.

Spector AA, John K, Fletcher JE (1969) Binding of long-chain fatty acids to bovine serum albumin. J Lipid Res 10:56-67.

Tanaka K, Smith CA (1978) Structure of the chicken's inner ear: SEM and TEM study. Am J Anat 153:251-272.

Tobias LD, Hamilton JG (1979) The effect of 5,8,11,14-eicosatetraynoic acid on lipid metabolism. Lipids 14:181-193.

Villarroel A, Schwarz TL (1996) Inhibition of the Kv4 (Shal) family of transient $\mathrm{K}^{+}$currents by arachidonic acid. J Neurosci 16:2522-2531.

Zhou W, Qian Y, Kunjilwar K, Pfaffinger PJ, Choe S (2004) Structural insights into the functional interaction of KChIP1 with Shal-type $\mathrm{K}^{+}$channels. Neuron 41:573-586.

Zidanic M, Fuchs PA (1995) Kinetic analysis of barium currents in chick cochlear hair cells. Biophys J 68:1323-1336. 